\title{
7. MAGNETOSTRATIGRAPHY OF ODP LEG 117 SEDIMENTS FROM THE OWEN RIDGE AND THE OMAN MARGIN, WESTERN ARABIAN SEA ${ }^{1}$
}

\author{
Akira Hayashida ${ }^{2}$ and Jan Bloemendal ${ }^{3}$
}

\begin{abstract}
Magnetic measurements were made on discrete samples from the Neogene pelagic and hemipelagic sediments recovered during ODP Leg 117. Polarity zones, usually identified for uppermost $200 \mathrm{~m}$, were correlated to the geomagnetic polarity time scale referring to biostratigraphic datums. Quality and resolution of the magnetostratigraphy was partly limited by the weak and relatively soft magnetic character of almost all intervals, and core disturbance by gas expansion at some Oman Margin sites. Clear polarity records of the Brunhes and Matuyama chrons ( $\mathrm{C} 1$ to $\mathrm{C} 2 \mathrm{r})$ were observed at Sites 724 and 727 on the Oman continental margin. Extended reversal records of the Pliocene were found at Site 722 on the Owen Ridge and Site 728 on the Oman Margin, and correlated to the Gauss to Gilbert chrons (C2A to C3).
\end{abstract}

\section{INTRODUCTION}

Leg 117 of the Ocean Drilling Program (ODP) recovered sediment cores more than $4300 \mathrm{~m}$ long in total length from 25 holes at 12 sites on the Indus fan, Owen Ridge, and Oman Margin in the northwest Arabian Sea. The primary purpose of the drilling was to recover continuous sections of Neogene sediments to obtain the paleoceanographic and paleoclimatic records of the Indian Ocean monsoon. In order to provide a chronostratigraphic framework for the Neogene sediments, we made a paleomagnetic study for most intervals of the recovered sections. The purpose of this paper is to present the results of magnetic measurements and their magnetostratigraphic interpretation. Almost all the samples from the Indus Fan site (Site 720) were measured on board the JOIDES Resolution, and the results are described in the initial reports (Prell, Niitsuma, et al., 1989). Here, we present an overview of the magnetostratigraphy of the Neogene sediments from the Owen Ridge and the Oman Margin.

On Leg 117, most holes were drilled using the advanced hydraulic piston core (APC) technique for the upper parts (to 50$100 \mathrm{mbsf}$ ) and the extended core barrel (XCB) for the deeper sequences. Although we measured the natural remanent magnetization (NRM) of archive halves of the APC cores using the pass-through cryogenic magnetometer (2-G Enterprises) on board the ship, the results were not useful for magnetostratigraphy. This was largely due to magnetic overprints probably induced by the coring process and which could not be removed by the shipboard pass-through alternating field (AF) demagnetizer. Therefore, our efforts were concentrated on measurements of discrete samples.

\section{METHODS}

Samples for magnetic measurements were collected from undisturbed intervals at all of the sites except Site 729, where one hole was drilled by rotary coring. In most cases, two discrete samples from one section ( $1.5 \mathrm{~m}$ long) were obtained for paleomagnetic study by inserting a $7 \mathrm{~cm}^{3}$ plastic cube into the split core face. When the sediments were semilithified, we used a thin ceramic knife to cut out samples into cubic shape. A small num-

\footnotetext{
${ }^{1}$ Prell, W. L., Niitsuma, N., et al., 1991. Proc, ODP, Sci. Results, 117: College Station, TX (Ocean Drilling Program).

${ }_{2}^{2}$ Laboratory of Earth Science, Doshisha University, Kyoto 602, Japan.

${ }^{3}$ Graduate School of Oceanography, University of Rhode Island, Narragansett, RI 02882, U.S.A.
}

ber of minicores was obtained from more lithified sediments by using a diamond-tipped rotary drill.

About half of the samples were measured on board the ship, using the MINISPIN fluxgate spinner magnetometer and the Schonstedt single-axis AF demagnetizer. For Site 721, we made stepwise AF demagnetization of the samples from all of the cores. For most of the other sites, the stepwise demagnetization on board was restricted to a small number of samples because of time constraints. Based on the AF demagnetization behavior of pilot samples, we demagnetized most samples at peak fields of 5 or $10 \mathrm{mT}$.

Shore-based measurements were made with a cryogenic magnetometer (ScT C-112 located at Kyoto University) with demagnetization using a three-axial tumbler with $\mu$-metal shields. Some of the samples left unmeasured on board, especially from the intervals around magnetic polarity boundaries, were subjected to stepwise AF demagnetization generally up to $25 \mathrm{mT}$. While similar magnetic components were observed, the shorebased AF demagnetization tended to reduce the NRM intensity more effectively than observed on board the ship. This may be due to the difference between static uniaxial AF application and the demagnetization with the three-axial tumbler (Collinson, 1983). We also carried out stepwise thermal demagnetization experiments for selected samples from the Oman Margin sites. The samples were removed from the plastic cubes, wrapped with aluminum foil, and heated in air within a shielded electric furnace. The residual magnetic field inside the furnace was less than $10 \mathrm{nT}$.

Magnetostratigraphy of the Leg 117 sediments is based on the inclination data obtained by a single step AF demagnetization on board and on shore. Assignment to the geomagnetic polarity time scale of Berggren et al. (1985) was made referring to the calcareous nannofossil and radiolarian biostratigraphy (Sato et al.; Spaulding; Nigrini; all in this volume). The polarity chron nomenclature in this paper follows the traditional system; however, terminology based on marine magnetic anomaly numbers by Harland et al. (1982) is also given. Lithologic, geochemical, and magnetic susceptibility data cited in this report are presented in the initial reports (Prell, Niitsuma, et al., 1989).

\section{OWEN RIDGE SITES}

The Owen Ridge is an aseismic ridge bounding the Indus Fan and the Owen Basin in the western Arabian Sea (Fig. 1). The sediment caps on the Owen Ridge were drilled at three sites (Site 721,722 , and 731) in water depths of $1900-1400 \mathrm{~m}$. The section recovered at the three sites ranges from the late Oligocene to the 


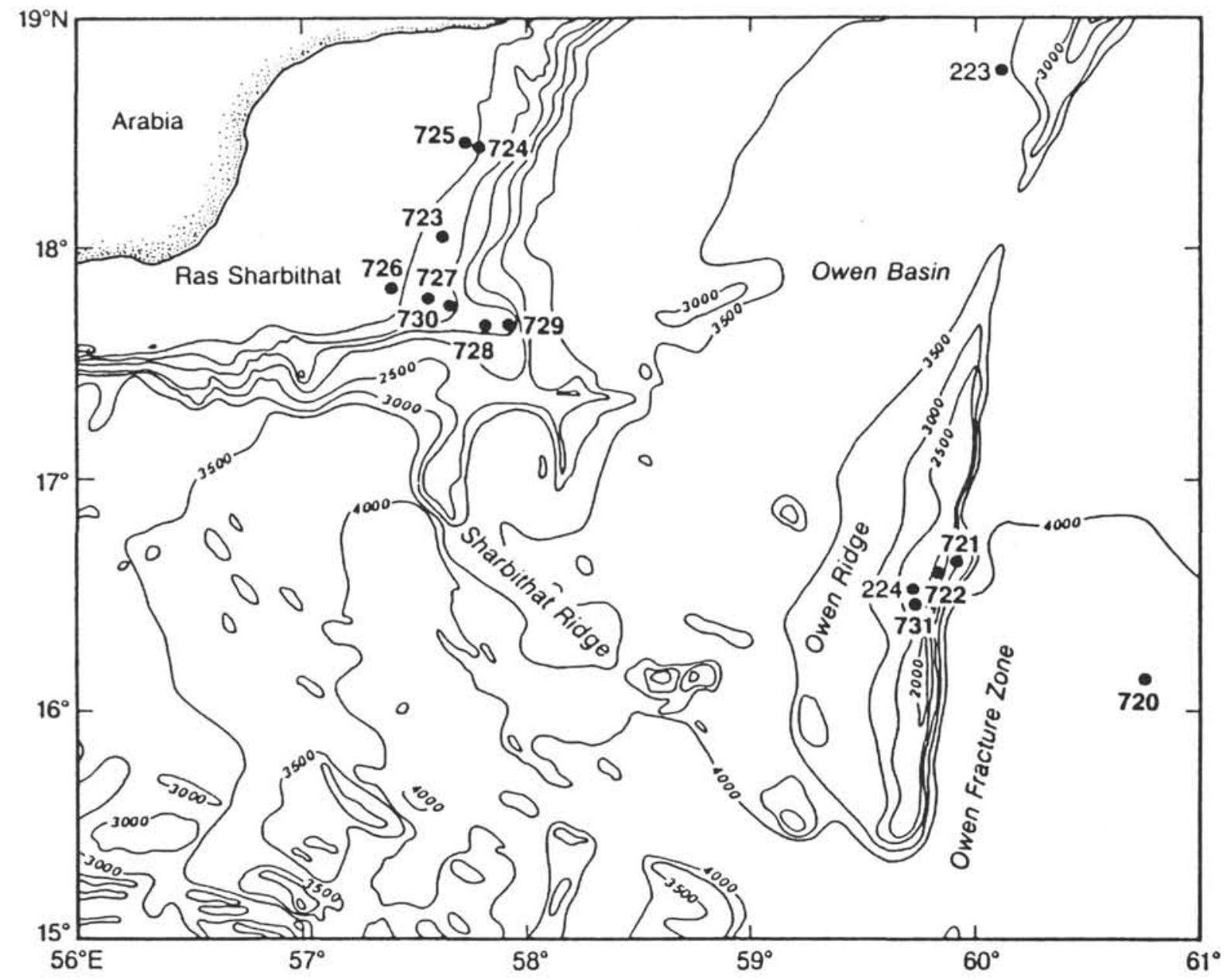

Figure 1. Location of Sites 720-731 on the Indus Fan, Owen Ridge, and Oman Margin in the western Arabian Sea.

late Pleistocene, and four major lithologic units were recognized. The oldest (Unit IV) comprises alternations of coarsegrained sand and silt turbidites and mud turbidites of the late Oligocene(?) to middle Miocene age. Units III consists of early to middle Miocene nannofossil chalk. Unit II is also composed of nannofossil chalk and ooze of late Miocene age, and is characterized by abundant biosiliceous components in contrast to the upper and lower units. Unit I is composed of foraminiferbearing to foraminifer-nannofossil ooze of late Miocene to late Pleistocene age, and shows strong cyclicity in coloration (alternating light and dark layers) and in whole-core magnetic susceptibility. While samples for magnetic measurements were collected through the four units, magnetostratigraphic information was obtained mainly from Unit I.

\section{Site 721}

Site 721 is located near the crest of the Owen Ridge in a water depth of $1945 \mathrm{~m}$ (Fig. 1). The section recovered from Holes $721 \mathrm{~A}$ and $721 \mathrm{~B}$ ranges from early Miocene to Holocene, including an hiatus equivalent to the nannofossil zones NN9 to NN5 between Unit III and II. Among the four lithologic units recognized on the ridge, Unit I occupies nine APC cores from Hole $721 \mathrm{~A}$ to a total depth of $86 \mathrm{mbsf}$ and the most extended portion, 0-289 mbsf, of Hole 721B. Paleomagnetic samples were obtained mainly from Unit I, that is, Cores $117-721 \mathrm{~A}-1 \mathrm{H}$ to $-9 \mathrm{H}$ (0-86 mbsf) and from Cores $117-721 \mathrm{~B}-5 \mathrm{H}$ to $-32 \mathrm{X}$.

Shipboard measurements were made with a blanket AF demagnetization at 10 or $15 \mathrm{mT}$. Stepwise demagnetization tests on pilot samples showed that demagnetization at 5 or $10 \mathrm{mT}$ erased a soft magnetic component, either a viscous remanent magnetization (VRM) or a coring-induced remanence. Remeasurement of the samples on shore resulted in rather ambiguous polarity zonation. Therefore our magnetostratigraphic interpretation of Site 721 is based on the shipboard results and the shorebased work on the samples left unmeasured on board the ship. Most of these samples were AF-demagnetized stepwise up to 30 $\mathrm{mT}$. The magnetic directions after AF demagnetization at 10 or $15 \mathrm{mT}$ were assumed to represent a characteristic magnetic direction (Fig. 2).

The shipboard measurements showed that the section from Hole $721 \mathrm{~A}$ is divided into at least three magnetic polarity zones (Fig. 3). The polarity transitions at 39 mbsf between Cores $117-$ $721 \mathrm{~A}-4 \mathrm{H}$ and $-5 \mathrm{H}$ and at $80 \mathrm{mbsf}$ in Core $117-721 \mathrm{~A}-9 \mathrm{H}$ was assigned to the base of the Jaramillo Subchronozone (C1r-1/C1r) and to the Matuyama/Gauss boundary $(\mathrm{C} 2 \mathrm{r} / \mathrm{C} 2 \mathrm{~A})$, respectively. Shore-based measurements revealed the occurrence of negative inclinations around $34 \mathrm{mbsf}$ in Core 117-721A-4H (Fig. 3). Two nannofossil datums, the last appearance datum (LAD) of Reticulofenestra asanoi $\mathrm{n}$. sp. and the first appearance datum (FAD) of Gephyrocapsa parallela, which predate the Brunhes/Matuyama (C1/C1r) boundary (Takayama and Sato, 1987) occur above 33 mbsf (Sato et al., this volume). It follows that the reversed polarity data around $34 \mathrm{mbsf}$ should be assigned not above the Jaramillo Subchronozone $(\mathrm{C} 1 \mathrm{r}-1)$, but below it. The normal polarity data in the lower part of Core $117-721 \mathrm{~A}-4 \mathrm{H}$ may correspond to the other polarity episode such as the Cobb 


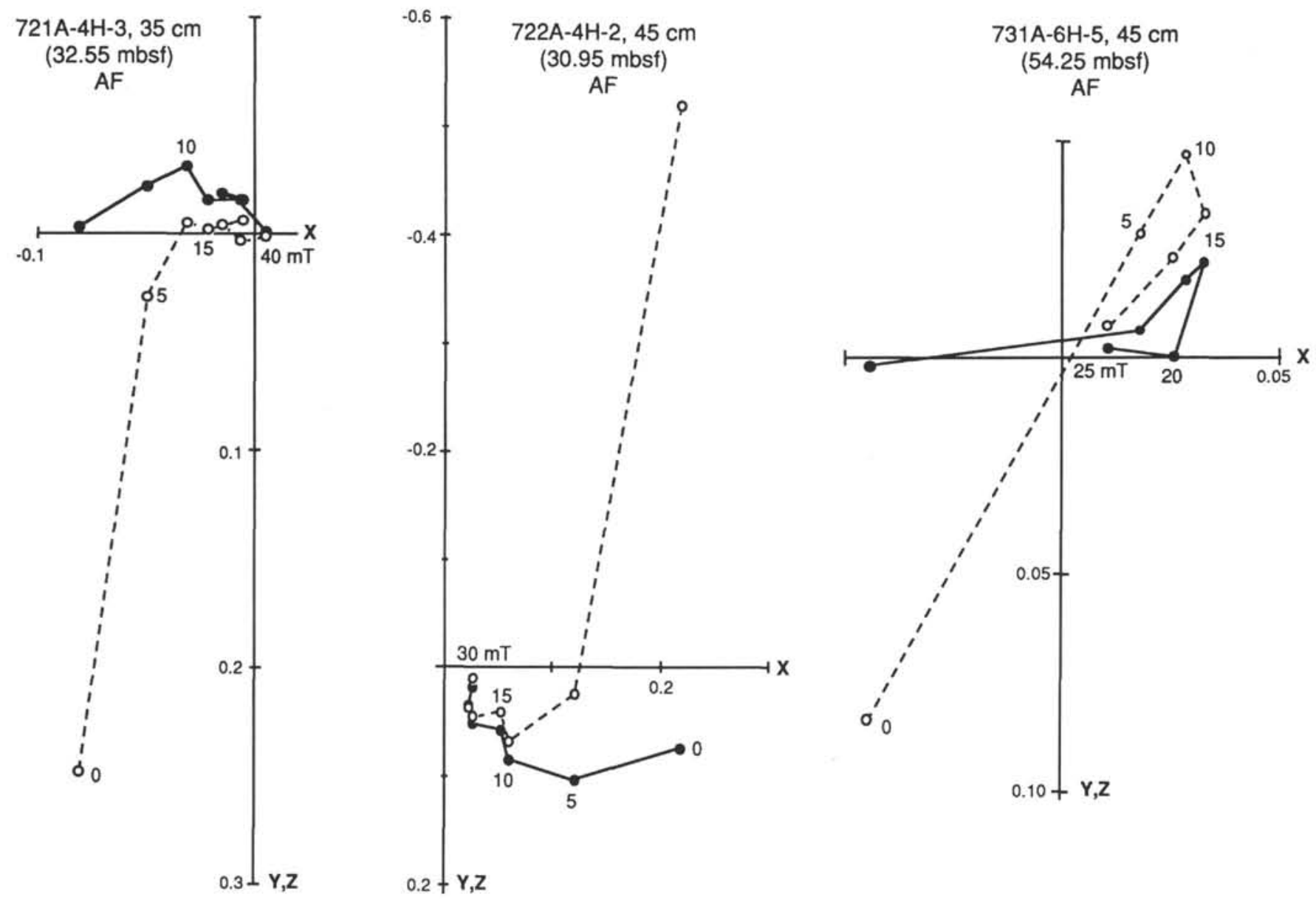

Figure 2. Examples of stepwise AF demagnetization data from the Owen Ridge Sites 721, 722, and 731. Closed and open circles represent magnetization vector end-points projected on the horizontal $(\mathrm{X}-\mathrm{Y})$ and vertical $(\mathrm{X}-\mathrm{Z})$ planes, respectively. The X-axis is perpendicular toward the split core face of the working half, and the Z-axis in the downward direction. Tick marks indicate division of magnetic moment in $\mathrm{mA} / \mathrm{m}$. The peak demagnetizing fields are given in $\mathrm{mT}$ for some points.

Mountain "event" (Mankinen et al., 1978; Clement and Robinson, 1987). The horizon of the Matuyama/Gauss boundary $(\mathrm{C} 2 \mathrm{r} / \mathrm{C} 2 \mathrm{~A})$ at $80 \mathrm{mbsf}$ seems to be confirmed by the shorebased results.

The sequence above $300 \mathrm{mbsf}$ in Hole 721B was divided into several polarity zones, and five magnetostratigraphic boundaries from Chronozone $5(\mathrm{C} 3 \mathrm{~A})$ to the Matuyama Chronozone (C2r) were tentatively determined on board the ship. The results of the stepwise AF demagnetization on shore generally support the polarity zonation of the shipboard data (Fig. 3). The depth of individual magnetostratigraphic datums, which were determined from the combined dataset are listed in Table 1. The assignment was checked using nannofossil datums (Sato et al., this volume) and radiolarian events (Nigrini, this volume).

The mean inclinations, determined by Kono's (1980) method, are $33^{\circ} \pm 6^{\circ}\left(95 \%\right.$ confidence limit) for Hole $721 \mathrm{~A}$ and $27^{\circ} \pm$ $4^{\circ}$ for Hole $721 \mathrm{~B}$. Both are concordant with the inclination of the geocentric axial dipole field $\left(30.9^{\circ}\right)$ expected from the site latitude $\left(16^{\circ} 41^{\prime} \mathrm{N}\right)$.

\section{Site 722}

Site 722 is located near the crest of the Owen Ridge at a water depth of $2028 \mathrm{~m}, 8 \mathrm{~km}$ southwest of Site 721 (Fig. 1). Two holes to total depths of $280.0 \mathrm{mbsf}(722 \mathrm{~A})$ and $565.1 \mathrm{mbsf}$ (722B) provided an early Miocene to late Pleistocene section, which is comparable to but more complete than Site 721. Litho-
Table 1. Locations of magnetostratigraphic datums in Holes 721A and 721B.

\begin{tabular}{|c|c|c|c|}
\hline Polarity boundary & $\begin{array}{l}\text { Age } \\
(\mathrm{Ma})\end{array}$ & Sample & $\begin{array}{l}\text { Depth } \\
\text { (mbsf) }\end{array}$ \\
\hline $\begin{array}{c}\text { Matuyama/Gauss } \\
(\mathrm{C} 2 \mathrm{r} / \mathrm{C} 2 \mathrm{~A})\end{array}$ & 2.47 & $\begin{array}{l}721 \mathrm{~A}-9 \mathrm{H}-2,146 \mathrm{~cm} \\
721 \mathrm{~A}-9 \mathrm{H}-3,35 \mathrm{~cm}\end{array}$ & $\begin{array}{l}79.76 \\
80.15\end{array}$ \\
\hline $\begin{array}{l}\text { Matuyama/Gauss } \\
\text { (C2r/C2A) }\end{array}$ & 2.47 & $\begin{array}{l}721 \mathrm{~B}-9 \mathrm{H}-6,115 \mathrm{~cm} \\
721 \mathrm{~B}-10 \mathrm{X}-1,35 \mathrm{~cm}\end{array}$ & $\begin{array}{l}85.05 \\
86.35\end{array}$ \\
\hline $\begin{array}{l}\text { Gauss/Gilbert } \\
\text { (C2A/C2Ar) }\end{array}$ & 3.40 & $\begin{array}{l}721 \mathrm{~B}-13 \mathrm{X}-2,35 \mathrm{~cm} \\
721 \mathrm{~B}-13 \mathrm{X}-2,115 \mathrm{~cm}\end{array}$ & $\begin{array}{l}116.65 \\
117.45\end{array}$ \\
\hline $\begin{array}{c}\text { Top of Nunivak(?) } \\
\text { (C3.1r/C3.2) }\end{array}$ & 4.10 & $\begin{array}{l}721 \mathrm{~B}-15 \mathrm{X}-3,35 \mathrm{~cm} \\
721 \mathrm{~B}-15 \mathrm{X}-3,115 \mathrm{~cm}\end{array}$ & $\begin{array}{l}137.45 \\
138.25\end{array}$ \\
\hline $\begin{array}{c}\text { Base of Nunivak(?) } \\
\text { (C3.2/C3.2r) }\end{array}$ & 4.24 & $\begin{array}{l}721 \mathrm{~B}-15 \mathrm{X}-6,35 \mathrm{~cm} \\
721 \mathrm{~B}-16 \mathrm{X}-1,34 \mathrm{~cm}\end{array}$ & $\begin{array}{l}141.95 \\
144.14\end{array}$ \\
\hline $\begin{array}{l}\text { Top of Sidufjall } \\
\text { (C3.2r/C3.2r-1) }\end{array}$ & 4.40 & $\begin{array}{l}721 \mathrm{~B}-16 \mathrm{X}-5,115 \mathrm{~cm} \\
721 \mathrm{~B}-16 \mathrm{X}-6,35 \mathrm{~cm}\end{array}$ & $\begin{array}{l}150.95 \\
151.66\end{array}$ \\
\hline $\begin{array}{l}\text { Base of Thvera } \\
\text { (C3.3/C3.3r) }\end{array}$ & 4.77 & $\begin{array}{l}721 \mathrm{~B}-18 \mathrm{X}-3,115 \mathrm{~cm} \\
721 \mathrm{~B}-18 \mathrm{X}-6,115 \mathrm{~cm}\end{array}$ & $\begin{array}{l}167.35 \\
171.85\end{array}$ \\
\hline $\begin{array}{l}\text { Gilbert/5 } \\
\qquad(\mathrm{C} 3 \mathrm{r} / \mathrm{C} 3 \mathrm{~A})\end{array}$ & 5.35 & $\begin{array}{l}721 \mathrm{~B}-22 \mathrm{X}-3,115 \mathrm{~cm} \\
721 \mathrm{~B}-22 \mathrm{X}-4,35 \mathrm{~cm}\end{array}$ & $\begin{array}{l}206.15 \\
206.85\end{array}$ \\
\hline
\end{tabular}

logic Unit I was observed above 221.5 mbsf, conformably overlying Unit II.

The magnetization of more than half of the samples from Units I and II was measured on board the ship with a blanket AF demagnetization mostly at $10 \mathrm{mT}$. No stepwise demagnet- 

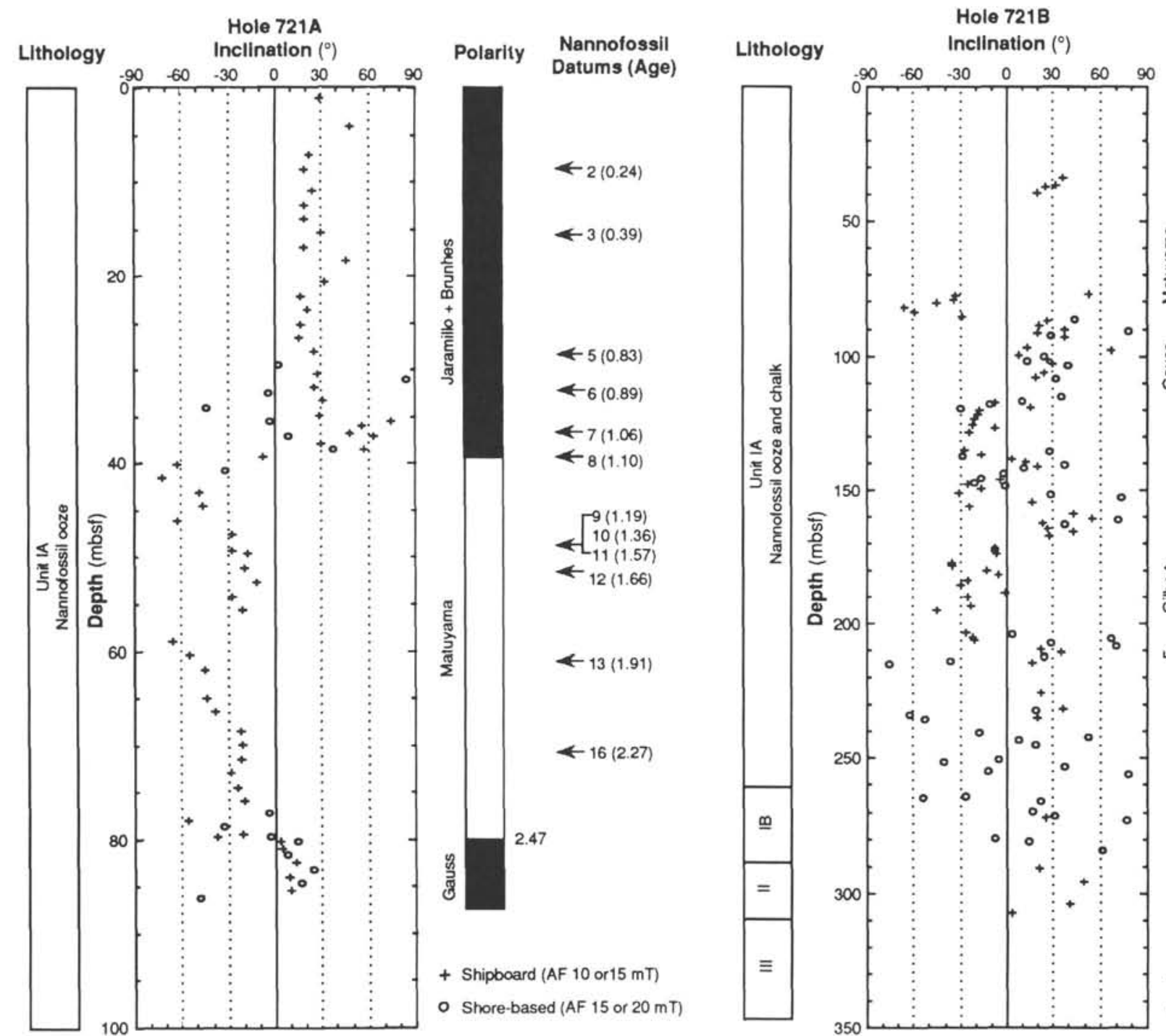

Polarity

Nannofossil Radiolarian

Datums (Age) Event Ages

Figure 3. Lithologic units, downhole inclination plots, and polarity assignment for Holes 721A and 721B on the Owen Ridge. Also shown are biostratigraphic datum levels relevant to correlation with polarity time scale (Sato et al., this volume; Nigrini, this volume). For Figures 3-6, 8, and 11-13, nannofossil datums are: 2: FAD Emiliania huxleyi (0.24 Ma), 3: LAD Pseudoemiliania lacunosa (0.39 Ma), 5: LAD Reticulofenestra asanoi n. sp. (0.83 Ma), 6: FAD Gephyrocapsa parallela (0.89 Ma), 7: Bottom of acme of Reticulofenestra asanoi n. sp. (1.06 Ma), 8: LAD Gephyrocapsa (large) (1.10 Ma), 9: LAD Helicosphaera sellii (1.19 Ma), 10: FAD Gephyrocapsa (large) (1.36 Ma), 11: LAD Calcidiscus macintyrei and FAD Gephyrocapsa oceanica (1.57 Ma), 12: FAD Gephyrocapsa caribbeanica (1.66 Ma), 13: LAD Discoaster brouweri (1.91 Ma), 16: LAD Discoaster pentaradiatus (2.27 Ma), 17: LAD Discoaster surculus (2.42 Ma), 18: LAD Discoaster tamalis (2.62 Ma), 19: LAD Reticulofenestra ampla n. sp. (2.62 Ma), 20: Top of "lower acme" of Crenalithus doronicoides (2.97 Ma), 21: LAD Reticulofenestra pseudoumbilica (3.56 Ma), NN12/NN11: LAD Discoaster Quinqueramus, NN10/NN9: LAD Discoaster hamatus, NN9/NN8: FAD Discoaster hamatus, NN8/NN7: FAD Catinaster coalitus. Radiolarian events are: LAD Lychnodictium audax (3.33-3.35 Ma), LAD Phormostichoartus doliolum (3.53-3.55 Ma), FAD Amphirhopalum ypsilon (3.77-3.79 Ma), FAD Spongaster tetras tetras (3.83-3.85 Ma), LAD Solenosohaera omnitubus (4.7-4.8 Ma), LAD Stichocorys bramlettei(4.9-5.0 Ma), LAD Acrobotrys tritubus (5.3-5.4 Ma), LAD Stichocorys jhonsoni (5.7-5.8 Ma), Spongaster delmontensis $\rightarrow$ Spongaster peregrina (6.16.7 Ma), LAD Calocycletta caepa (6.2-6.6 Ma). 
izations were made on board because of time constraints. Stepwise demagnetization on shore showed that a characteristic magnetic component is isolated above $10 \mathrm{mT}$ (Fig. 2). AF demagnetization above $20 \mathrm{mT}$ tended to result in erratic changes of NRM, which is probably due to anhysteretic remanent magnetization (ARM) superimposed during the AF treatment and the weak magnetic intensities (generally less than $0.1 \mathrm{~mA} / \mathrm{m}$ ).

Figure 4 shows plots of inclinations obtained on board and by shore-based measurements. The shipboard data suggested that the sections in Hole 722A and 722B can be divided into several polarity zones above 200 mbsf. Below this level, about half of the data was removed by the filtering process (circular standard deviation greater than $40^{\circ}$ ), and no polarity zone can be identified clearly. The inclinations measured after 10 or $15 \mathrm{mT}$ AF demagnetization on shore were generally consistent with the shipboard data. A significant difference is, however, observed in the interval 30-45 mbsf in Hole 722A (Core 117-722A-5H). We interpret that the positive inclinations of the shipboard results are due to insufficient removal of secondary magnetization. The polarity boundary at about $38 \mathrm{mbsf}$, determined with the shorebased data, is assigned to the bottom of the Jaramillo Subchronozone $(\mathrm{C} 1 \mathrm{r}-1 / \mathrm{C} 1 \mathrm{r})$. Although a reversed polarity sample at 33.95 mbsf, and possibly the shallow inclinations below it, may represent the reversed polarity interval above the Jaramillo Subchronozone (C1r-1), the Brunhes/Matuyama boundary (C1/ $\mathrm{C} 1 \mathrm{r})$ and the top of Jaramillo $(\mathrm{C} 1 \mathrm{r} / \mathrm{C} 1 \mathrm{r}-1)$ are not fully defined. These two boundaries were not detected in Hole 722B either, and the uppermost clear polarity boundary in Hole 722B at around $40 \mathrm{mbsf}$ is assumed to be the lower Jaramillo boundary (C1r-1/Clr). This assignment is concordant with biostratigraphic data from the two holes (Prell, Niitsuma, et al., 1989; Sato et al., this volume).

Depths of the magnetostratigraphic datums in Holes 722A and 722B are listed in Table 2, including boundaries between the Matuyama ( $\mathrm{C} 1 \mathrm{r}$ to $\mathrm{C} 2 \mathrm{r}$ ), Gauss (C2A), Gilbert (C2Ar to $\mathrm{C} 3 \mathrm{r}$ ), and Chronozone $5(\mathrm{C} 3 \mathrm{~A})$. As shown in Figure 4, these assignments are concordant with the horizons of the Pliocene radiolarian events (Nigrini, this volume), of which ages were paleomagnetically calibrated using DSDP and piston cores from the Equatorial Indian and Pacific Oceans (Johnson and Nigrini, 1985; Johnson et al., 1989). Polarity intervals of about or less than $10^{5} \mathrm{yr}$ were not clearly detected; as at Site 721 , the Olduvai (C2), Kaena (C2A-1), and Mammoth (C2A-2) subchronozones were not observed in Hole 722A and 722B.

The mean inclinations of Holes $722 \mathrm{~A}$ and $722 \mathrm{~B}$ are $30^{\circ} \pm 4^{\circ}$ and $28^{\circ} \pm 4^{\circ}$, respectively. These values agree with the expected inclination $\left(30.8^{\circ}\right.$ at this site $\left(16^{\circ} 37^{\prime} \mathrm{N}\right)$.

\section{Site 731}

Site 731 is located on the westward slope of the Owen Ridge in a water depth of $2366 \mathrm{~m}$, just below the ridge crest (Fig. 1). A sequence of early Miocene to Holocene pelagic sediment (Units I-IV) of about $400 \mathrm{~m}$ thick was recovered from Hole 731A. Two hiatuses were recognized at 97 mbsf and $117 \mathrm{mbsf}$ in Unit I, where middle Pliocene and lowermost Pliocene to uppermost Miocene sediments are missing. The radiolarian biostratigraphic data (Prell, Niitsuma, et al., 1989) suggest that the two hiatuses correspond to time intervals from $2.4 \mathrm{Ma}$ to less than $3.4 \mathrm{Ma}$ at $97 \mathrm{mbsf}$ and from $4.3 \mathrm{Ma}$ to $6.1 \mathrm{Ma}$ at $117 \mathrm{mbsf}$.

The NRM of the samples from Hole 731A was measured with a blanket $\mathrm{AF}$ demagnetization at 5 or $10 \mathrm{mT}$ on board. Shore-based analysis showed that most samples above the hiatus at 117 mbsf carried a characteristic magnetization, which was usually observed upon progressive AF demagnetization above 10 $\mathrm{mT}$. Some of the samples, however, changed NRM directions after $15 \mathrm{mT}$ AF demagnetization, as shown in Figure 2.
Figure 5 shows inclination plots of the shipboard results along with those determined at 15 or $20 \mathrm{mT}$ of the stepwise AF demagnetization on shore. In the shipboard results, the uppermost polarity boundary was found between 50 and 55 mbsf. As in the case of Hole 722A, however, the samples around $50 \mathrm{mbsf}$ measured on shore showed negative inclinations, suggesting the reverse-to-normal transition is located at about 46 mbsf. We assume that this transition corresponds to the lower Jaramillo boundary $(\mathrm{C} 1 \mathrm{r}-1 / \mathrm{C} 1 \mathrm{r})$, based on occurrence of the two nannofossil datums (LAD of Reticulofenestra asanoi n. sp. and FAD of Gephyrocapsa parallela) between 40 and 45 mbsf (Sato et al., this volume). Above these datums, two negative inclination values may represent the reversed polarity interval between the Brunhes/Matuyama boundary $(\mathrm{C} 1 / \mathrm{Clr})$ and the top of Jaramillo Subchronozone $(\mathrm{C} 1 \mathrm{r} / \mathrm{C} 1 \mathrm{r}-1)$, as listed in Table 3 .

Most samples between 46 and $110 \mathrm{mbsf}$ seem to have reversed polarity. This suggest that the sediment above the hiatus at 97 mbsf is assigned to the Matuyama Chronozone (C1r to $\mathrm{C} 2 \mathrm{r}$ ). Positive inclination data of some shipboard samples at around 80 mbsf may be correlative to the Olduvai Subchronozone (C2). Most of the Gauss Chronozone (C2A) is apparently missing. Below the hiatus at 117 mbsf, significant numbers of readings from Units I and II were eliminated because of large circular standard deviation $\left(>40^{\circ}\right)$, and no magnetostratigraphic interpretation is possible.

\section{OMAN MARGIN SITES}

The Oman Margin sites (723 through 730) are located on the continental shelf and slope off Oman, of which water depths range from 310 to $1500 \mathrm{~m}$ (Fig. 1). The main target of this portion of Leg 117 was to recover organic-rich hemipelagic sediments of Miocene to Holocene age. The dominant lithology was olive to green calcareous ooze to clayey silts, which were deposited under the activity of monsoon-induced upwelling and the related oxygen minimum zone.

\section{Site 723}

Site 723 is located near the center of the upper slope basin in water depth of about $800 \mathrm{~m}$ (Fig. 1), and has the highest sedimentation rate for the latest Pliocene to Pleistocene $(\sim 175 \mathrm{~m} /$ m.y.) of all of Leg 117 sites. Samples for paleomagnetic study were obtained from two $\mathrm{APC} / \mathrm{XCB}$ holes (723A and 723B). Both were drilled to a depth of about $430 \mathrm{mbsf}$.

Shipboard results from Hole 723A showed that the magnetic intensities dropped down from about $1 \mathrm{~mA} / \mathrm{m}$ to less than 0.1 $\mathrm{mA} / \mathrm{m}$ at around $100 \mathrm{mbsf}$. The magnetic inclinations above 100 mbsf are consistently positive, suggesting correlation to the Brunhes Chronozone (C1). The mean value is $27^{\circ} \pm 4^{\circ}$, which is smaller than the inclination of the geocentric axial dipole field $\left(33.1^{\circ}\right)$ at this site $\left(18^{\circ} 03^{\prime} \mathrm{N}\right)$. Although the interval below 100 mbsf should be mostly correlative to the Matuyama Chronozone, the inclinations were rather scattered, showing no consistent reversed polarities. The section below $100 \mathrm{~m}$ of Hole 723B gave similar results, with the exception of the interval from 200 to 250 mbsf which had consistent reversed polarities with higher intensities (Fig. 6). The samples from Hole 723A measured on board the ship were remeasured on shore, using AF demagnetization steps of 10,20 , and $30 \mathrm{mT}$. Although this increased the number of negative inclination data below 100 mbsf, the magnetostratigraphy was still unresolved.

Stepwise AF demagnetization up to $30 \mathrm{mT}$ revealed the existence of a characteristic magnetic component in normal polarity above 100 mbsf. Below this depth, however, a marked decrease of NRM intensity prevented reliable detection of a magnetic component. A few samples have possibly preserved a primary magnetization. These include a normal polarity magnetization 

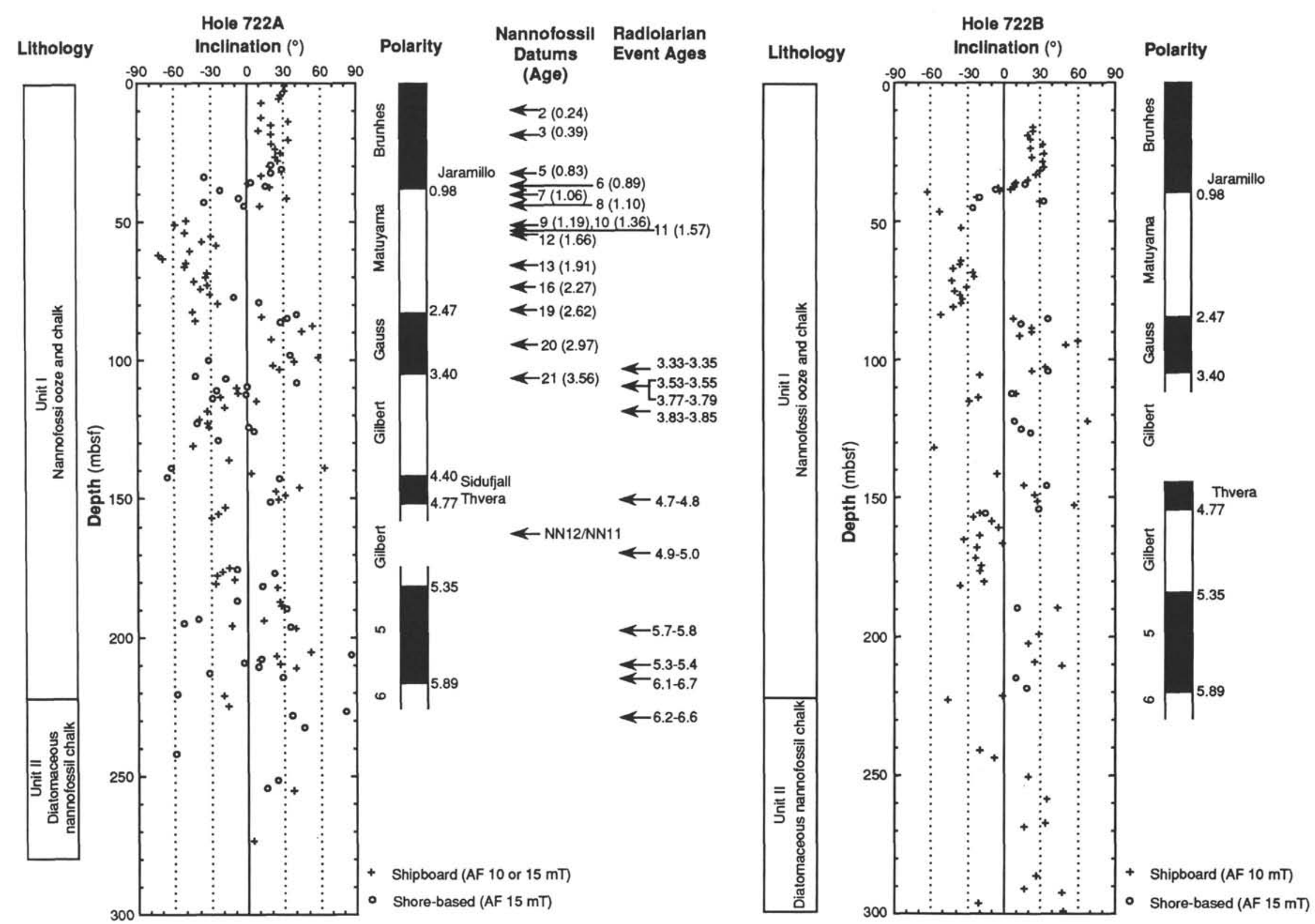

Figure 4. Lithologic units, downhole inclination plots, polarity assignment, and biostratigraphic datum levels (Sato et al., this volume; Nigrini, this volume) for Holes 722A and 722B on the Owen Ridge. See Figure 3 for explanation. 
Table 2. Locations of magnetostratigraphic datums in Holes 722A and 722B.

\begin{tabular}{|c|c|c|c|c|c|}
\hline Polarity boundary & $\begin{array}{l}\text { Age } \\
\text { (Ma) }\end{array}$ & Sample & $\begin{array}{l}\text { Depth } \\
\text { (mbsf) }\end{array}$ & Sample & $\begin{array}{l}\text { Depth } \\
\text { (mbsf) }\end{array}$ \\
\hline & & Hole 722A & & Hole 722B & \\
\hline Base of Jaramillo & 0.98 & $4 \mathrm{H}-6,115 \mathrm{~cm}$ & 37.65 & $5 \mathrm{H}-4,100 \mathrm{~cm}$ & 39.80 \\
\hline$(\mathrm{Clr}-1 / \mathrm{Clr})$ & & $4 \mathrm{H}-7,40 \mathrm{~cm}$ & 38.40 & $5 \mathrm{H}-5,30 \mathrm{~cm}$ & 40.60 \\
\hline Matuyama/Gauss & 2.47 & $9 \mathrm{H}-4,115 \mathrm{~cm}$ & 82.45 & $10 \mathrm{X}-1,110 \mathrm{~cm}$ & 83.80 \\
\hline$(\mathrm{C} 2 \mathrm{r} / \mathrm{C} 2 \mathrm{~A})$ & & $9 \mathrm{H}-5,45$ & 83.25 & $10 X-2,100 \mathrm{~cm}$ & 85.20 \\
\hline Gauss/Gilbert & 3.40 & $11 X-5,115 \mathrm{~cm}$ & 103.95 & $12 \mathrm{X}-2,100 \mathrm{~cm}$ & 104.00 \\
\hline (C2A/C2Ar) & & $11 \times-7,15 \mathrm{~cm}$ & 105.35 & $12 \mathrm{X}-3,108 \mathrm{~cm}$ & 105.58 \\
\hline Top of Sidufjall & 4.40 & $15 \mathrm{X}-5,115 \mathrm{~cm}$ & 142.05 & & \\
\hline (C $3.2 \mathrm{r} / \mathrm{C} 3.2 \mathrm{r}-1)$ & & $15 X-6,45 \mathrm{~cm}$ & 142.85 & & \\
\hline Base of Thvera & 4.77 & $16 \mathrm{X}-5,40 \mathrm{~cm}$ & 151.00 & $17 X-2,100 \mathrm{~cm}$ & 152.40 \\
\hline (C3.3/C3.3r) & & $16 \mathrm{X}-6,120 \mathrm{~cm}$ & 153.30 & $17 X-4,100 \mathrm{~cm}$ & 155.40 \\
\hline Gilbert/Chronozone 5 & 5.35 & $19 X-5,113 \mathrm{~cm}$ & 180.73 & $20 \mathrm{X}-2,99 \mathrm{~cm}$ & 181.39 \\
\hline$(\mathrm{C} 3 \mathrm{r} / \mathrm{C} 3 \mathrm{~A})$ & & $19 X-6,45 \mathrm{~cm}$ & 181.55 & $21 \mathrm{X}-1,110 \mathrm{~cm}$ & 189.60 \\
\hline Chronozone $5 / 6$ & 5.89 & $23 \mathrm{X}-2,44 \mathrm{~cm}$ & 214.34 & $24 \mathrm{X}-1,100 \mathrm{~cm}$ & 218.50 \\
\hline (C3A/C3Ar) & & $23 \mathrm{X}-6,47 \mathrm{~cm}$ & 220.37 & $24 \mathrm{X}-3,100 \mathrm{~cm}$ & 221.50 \\
\hline
\end{tabular}

detected through stepwise thermal demagnetization of Sample 117-723A-29X-5, $57 \mathrm{~cm}$, at $275.27 \mathrm{mbsf}$ (Fig. 7). While positive inclination data are dominant between 250 and $280 \mathrm{mbsf}$, the nannofossil biostratigraphy (Spaulding, this volume) suggested that this interval is above the Olduvai Subchronozone (C2).

As discussed in the initial reports, the low NRM intensity below 100 mbsf could have several causes: (1) a small flux of fine magnetic grains to the sediments; (2) diagenetic alteration of magnetic grains by reduction possibly to iron sulfide; and (3) randomization of magnetic grains by gas expansion, which made abundant voids in the core sediments, especially below $70 \mathrm{mbsf}$.

Reduction diagenesis of titanomagnetite to iron sulfide (2) has been observed in organic-rich sediments in various marine environments (e.g., Kobayashi and Nomura, 1972; Karlin and Levi, 1983; 1985; Canfield and Berner, 1987; Channell et al., 1990). The magnetite dissolution and formation of iron sulfide occur as a result of the activity of sulfate-reducing bacteria, which decompose organic matter (Karlin and Levi, 1985). The high concentration of organic carbon throughout the cores and the rapid sulfate depletion in pore-water by 50 mbsf observed at Site 723A (Prell, Niitsuma, et al., 1989) suggest the downward decrease in NRM intensity was caused by the reduction diagenesis. The shipboard observation of sediment mineralogy showed occurrence of pyrite in significant quantities in the sediment residues from Hole 723A. Thus, the diagenetic dissolution of magnetic grains by reduction to iron sulfide evidently affected the remanent magnetization of the Site 723 sediments.

The paleomagnetic directions might have survived the partial diagenesis, if enough magnetic grains remained less altered and had stable magnetizations. However, the likelihood of a paleomagnetic record being preserved is further reduced through disturbance of the sediments due to gas expansion (3, above). An exceptionally consistent record of reversed polarities was found in the interval from 200 to 250 mbsf of Hole 723B (Cores 117$723 \mathrm{~B}-23 \mathrm{X}$ to $-27 \mathrm{X}$ ), whereas the equivalent interval of Hole $723 \mathrm{~A}$ had scattered inclinations (Fig. 6). Almost $100 \%$ of the sediments was recovered from this interval of Hole 723B, and is supposedly less disturbed compared with Hole 723A. This fact implies that the randomization of magnetic grains by gas expansion (3) had also affected the quality of the paleomagnetic records from Site 723 .

\section{Site 724}

Site 724 is located in the northern part of the upper slope basin drilled at Site 723, with a shallower water depth of about 600 $\mathrm{m}$ (Fig. 1). Two holes (724B and 724C) penetrated the section about $250 \mathrm{~m}$ thick, which consists of green to olive green calcar- eous clayey silt with high organic carbon content, similar to Site 723. While gas expansion was again recognized, the total core recovery was improved. Sulfate is sharply decreased down to about 50 mbsf but never completely depleted. Organic matter degradation by sulfate reduction was not obvious.

Magnetostratigraphy of the sediments from Holes 724B and $724 \mathrm{C}$ was resolved by the shipboard magnetic measurements. The NRM of one sample per section was measured after AF demagnetization at $10 \mathrm{mT}$, and at $5 \mathrm{mT}$ below $210 \mathrm{mbsf}$ of Hole 724C. Stepwise AF demagnetization for some samples from Hole 724B showed that the characteristic magnetic component was observed in the coercivity range from 10 to $30 \mathrm{mT}$. The two holes showed consistent magnetic polarity records, including the Brunhes/Matuyama (C1/C1r) and Matuyama/Gauss $(\mathrm{C} 2 \mathrm{r} /$ $\mathrm{C} 2 \mathrm{~A}$ ) boundaries and the Jaramillo $(\mathrm{C} 1 \mathrm{r}-1)$ and Olduvai $(\mathrm{C} 2)$ Subchronozones.

Shore-based analysis was made involving remeasurement of the shipboard samples at $15 \mathrm{mT}$ and stepwise AF demagnetization of the samples which had not been measured on the ship. Thermal demagnetization of selected samples revealed that the NRM mostly decayed by heating up to $250^{\circ} \mathrm{C}$ (Fig. 7). As shown by the plots of all the samples from Holes 724B and 724C (Fig. $8)$, AF demagnetization at $15 \mathrm{mT}$ made the inclinations rather scattered and the intensities as weak as about $0.1 \mathrm{~mA} / \mathrm{m}$, especially around the Jaramillo Subchronozones $(\mathrm{C} 1 \mathrm{r}-1)$ and in the Gauss Chronozone (C2A). The inclination data above $210 \mathrm{mbsf}$ of Hole $724 \mathrm{~B}$ give the mean values of $32^{\circ} \pm 6^{\circ}$ for the normal polarity intervals and of $27^{\circ} \pm 4^{\circ}$ for the reversed polarity intervals. The mean inclination of the reversed polarity parts is shallower than expected from the geocentric axial dipole field $\left(33.8^{\circ}\right.$ at $\left.18^{\circ} 28^{\prime} \mathrm{N}\right)$. This may be due to insufficient removal of secondary magnetization of the reversed polarity samples.

Table 4 lists the magnetostratigraphic datum levels in Holes $724 \mathrm{~B}$ and $724 \mathrm{C}$, which are partly modified from the shipboard results. Some datum levels, including the top and base of the Olduvai Subchronozones (C2), were further confined using the additional polarity data. The assignment of the Olduvai is consistent with occurrence of the nannofossil datums, FAD of $\mathrm{Ge}$ phyrocapsa Caribbeanica, indicative of the Pleistocene/Pliocene boundary, and LAD of Discoaster brouweri (Spaulding, this volume). Because the samples from the 185-200 mbsf of Hole $724 \mathrm{C}$ showed negative inclinations, the Matuyama/Gauss $(\mathrm{C} 2 \mathrm{r} / \mathrm{C} 2 \mathrm{~A})$ boundary was assumed to be at about $200 \mathrm{mbsf}$ in both holes, rather than the horizons from 185 to $190 \mathrm{mbsf}$ determined on board ship. Reversed polarity records expected in the Gauss Chronozone ( $\mathrm{C} 2 \mathrm{~A}$ ) were not detected due to the weak magnetic intensity in this interval. 


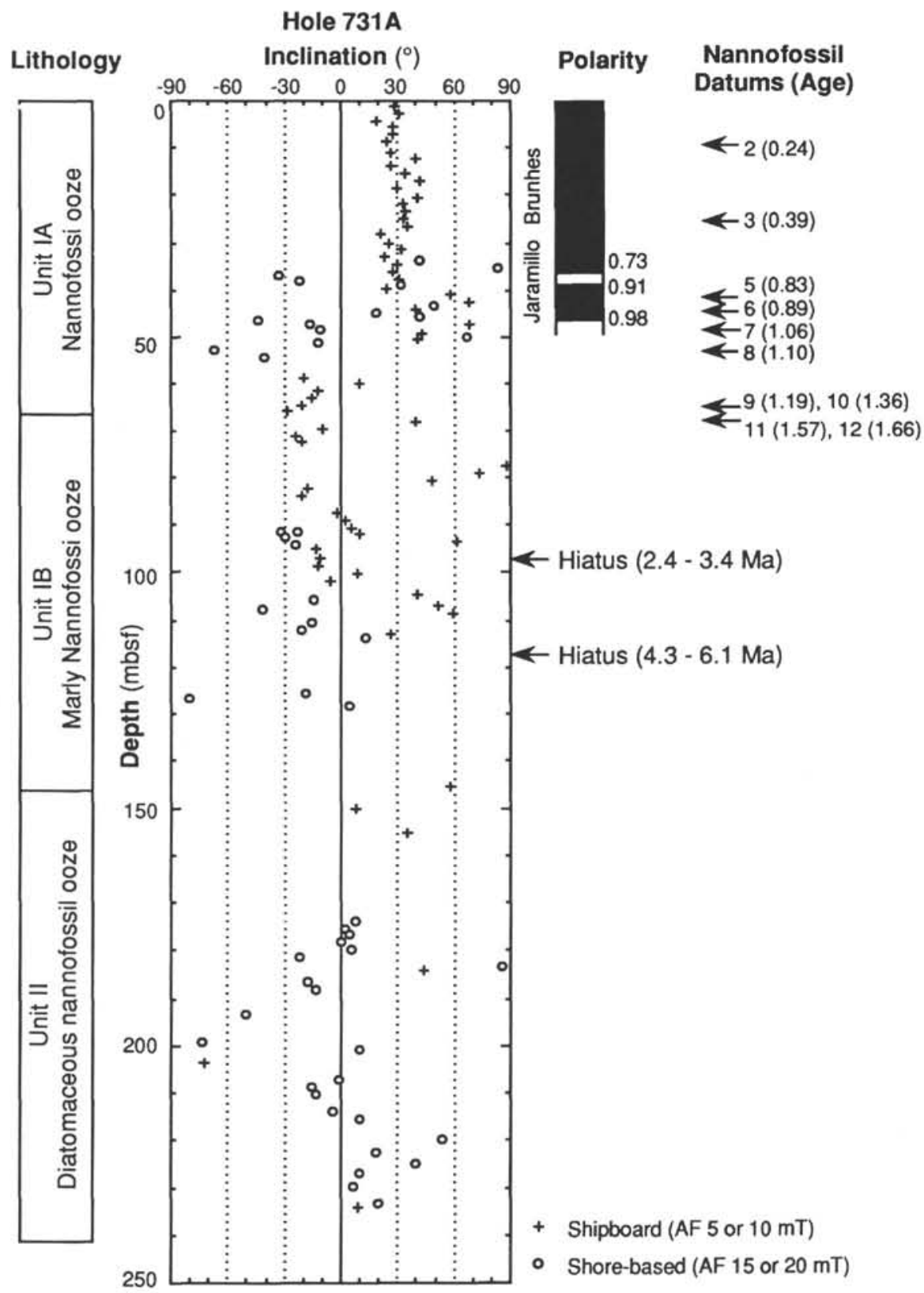

Figure 5. Lithologic units, downhole inclination plots, polarity assignment, and biostratigraphic datum levels (Sato et al., this volume) for Hole 731A on the Owen Ridge. See Figure 3 for explanation.

Site 725

Table 3. Locations of magnetostratigraphic datums in Holes 731A.

\begin{tabular}{|c|c|c|c|}
\hline Polarity boundary & $\begin{array}{l}\text { Age } \\
\text { (Ma) }\end{array}$ & Sample & $\begin{array}{l}\text { Depth } \\
\text { (mbsf) }\end{array}$ \\
\hline Brunhes/Matuyama(?) & 0.73 & $4 \mathrm{H}-5,45 \mathrm{~cm}$ & 35.25 \\
\hline$(\mathrm{C} 1 / \mathrm{Clr})$ & & $4 \mathrm{H}-6,45 \mathrm{~cm}$ & 36.75 \\
\hline $\begin{array}{l}\text { Top of Jaramillo(?) } \\
(\mathrm{Cl} 1 \mathrm{r} / \mathrm{Clr}-1)\end{array}$ & 0.91 & $\begin{array}{l}4 \mathrm{H}-7,43 \mathrm{~cm} \\
5 \mathrm{H}-1,45 \mathrm{~cm}\end{array}$ & $\begin{array}{l}38.23 \\
38.75\end{array}$ \\
\hline $\begin{array}{l}\text { Base of Jaramillo } \\
\text { (C1r-1/C1r) }\end{array}$ & 0.98 & $\begin{array}{l}5 \mathrm{H}-5,115 \mathrm{~cm} \\
5 \mathrm{H}-6,45 \mathrm{~cm}\end{array}$ & $\begin{array}{l}45.45 \\
46.25\end{array}$ \\
\hline
\end{tabular}

Site 725 is located on the landward edge of the upper slope basin at about $310 \mathrm{~m}$ deep, to the west of Site 724 (Fig. 1). The sedimentary sequence of about $160 \mathrm{~m}$ recovered from Hole $725 \mathrm{C}$ has a lithology similar to Site 723 and 724 , but includes coarser materials and less organic carbon.

The remanent magnetization of most of the samples from Hole $725 \mathrm{C}$ was measured after AF demagnetization at 5 or 10 $\mathrm{mT}$ on board the ship. Excluding data with circular standard deviation greater than $40^{\circ}$ and also the poor core recovery in this hole limited the amount of reliable data points and prevents confident correlation with the polarity time scale. Referring to the calcareous nannoplankton stratigraphy, only the possible horizons of the Brunhes/Matuyama $(\mathrm{Cl} / \mathrm{Clr})$ boundary and 


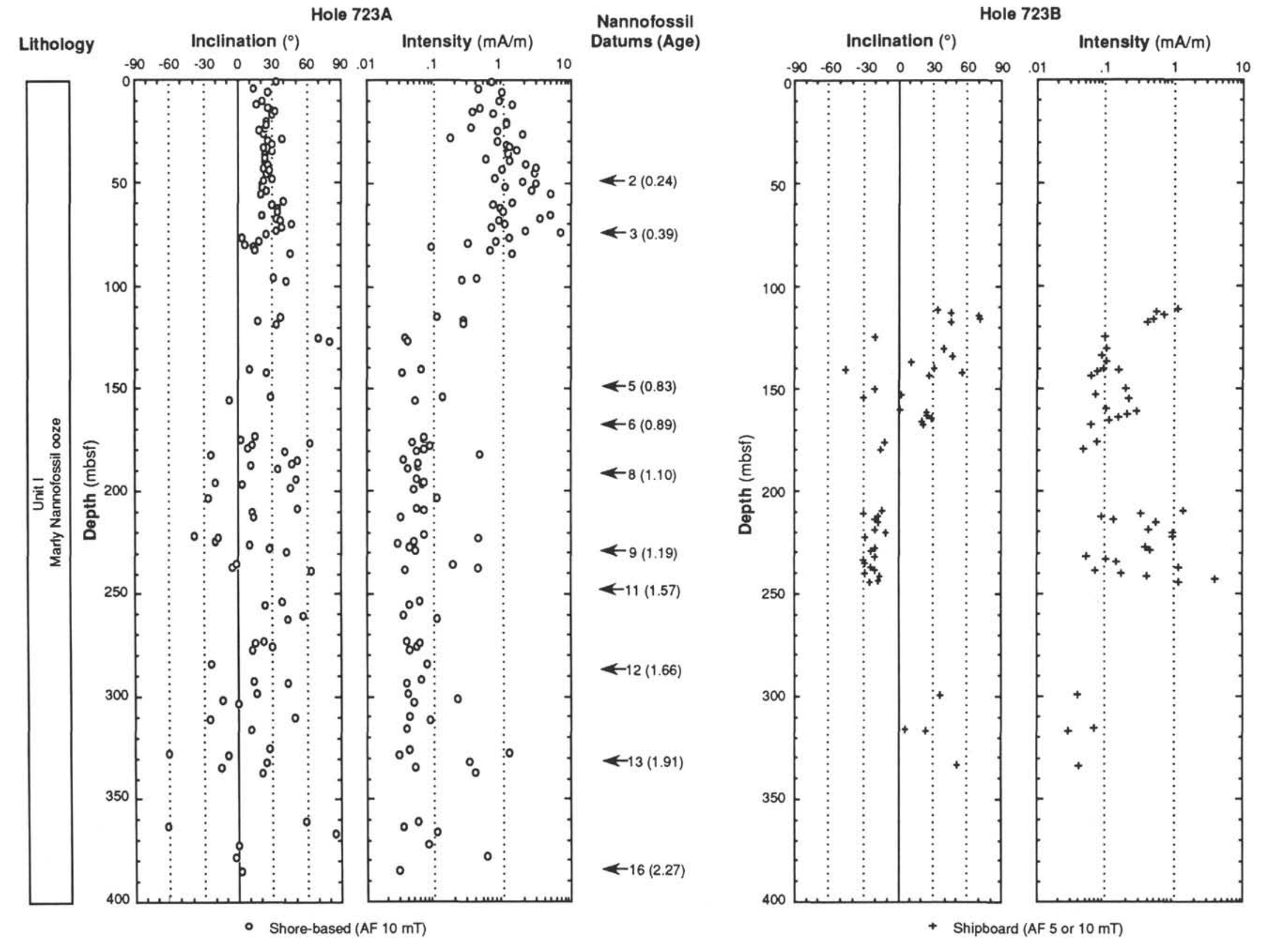




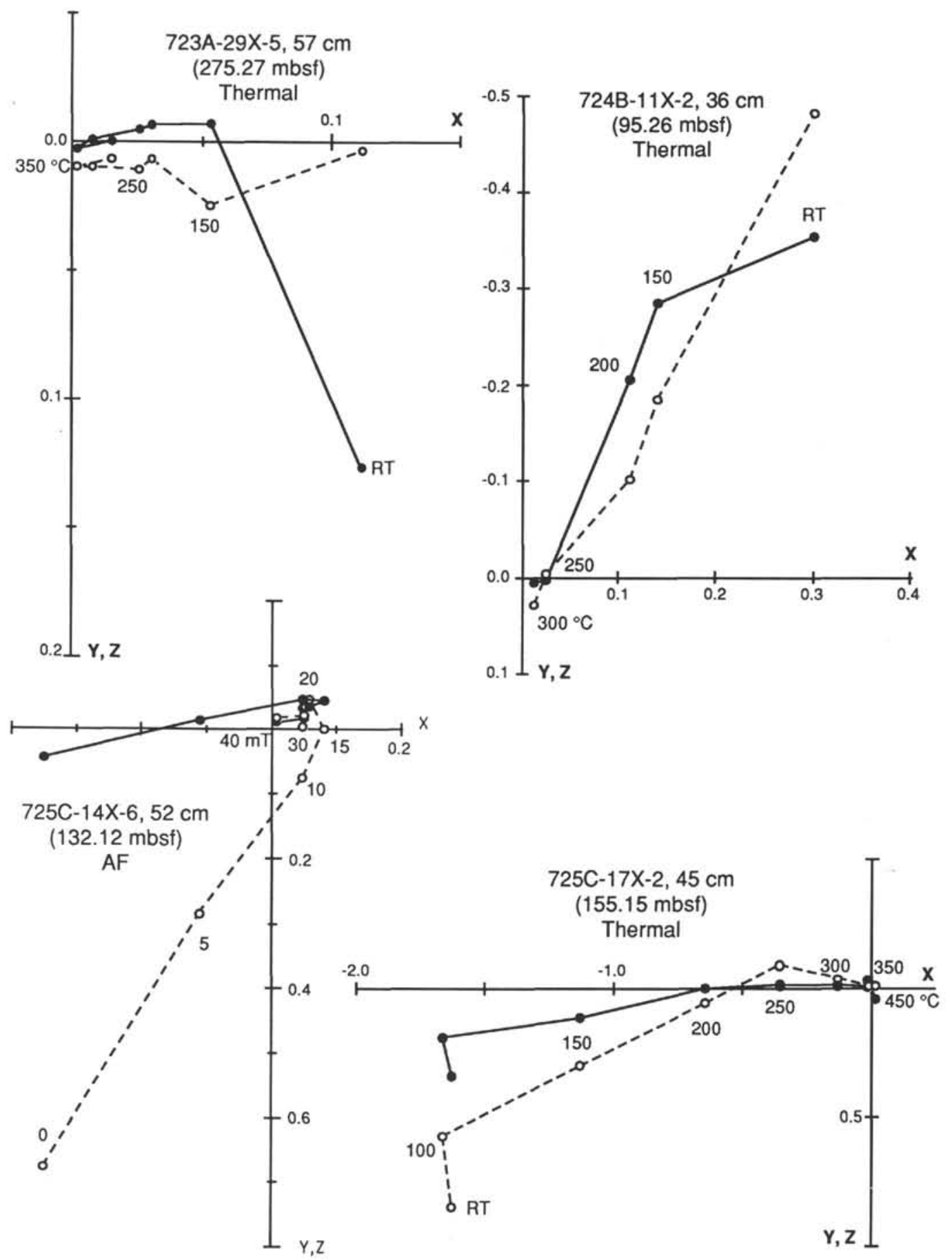

Figure 7. Examples of AF and thermal demagnetization data from the Oman Margin Sites 723, 724, and 725. The demagnetization temperatures are given in degrees Celsius for some points. See Figure 2 for explanation.

the Jaramillo (C1r-1) Subchronozone were inferred from the shipboard results.

Stepwise AF and thermal demagnetization were made on the samples which had been left unmeasured. Although consistent positive inclinations around $30^{\circ}$ had been obtained from the sediments down to about $70 \mathrm{mbsf}$, stable magnetizations were rarely obtained during the progressive demagnetization; the remanent magnetization showed unstable behavior in response to the demagnetization in peak AF's higher than $15 \mathrm{mT}$. This may reflect the presence of abundant terrigenous materials, which possibly include coarser magnetic grains. Most of the samples from the interval below 100 mbsf preserved two magnetic components (Fig. 7). The soft component, distributed in the coercivity range below $20 \mathrm{mT}$, could be of viscous remanent magnetization (VRM). Linear decay of the stable component toward the origin was attained by thermal demagnetization above $250^{\circ} \mathrm{C}$. We assume that the high coercivity and high temperature component is the primary magnetization.

Figure 9 shows plots of the magnetic inclinations and intensities determined by shore-based AF ( 20 or $25 \mathrm{mT})$ or thermal $\left(250^{\circ} \mathrm{C}\right)$ demagnetization, along with the shipboard results $(5$ or $10 \mathrm{mT})$. Although exact horizons of the magnetostratigraphic 


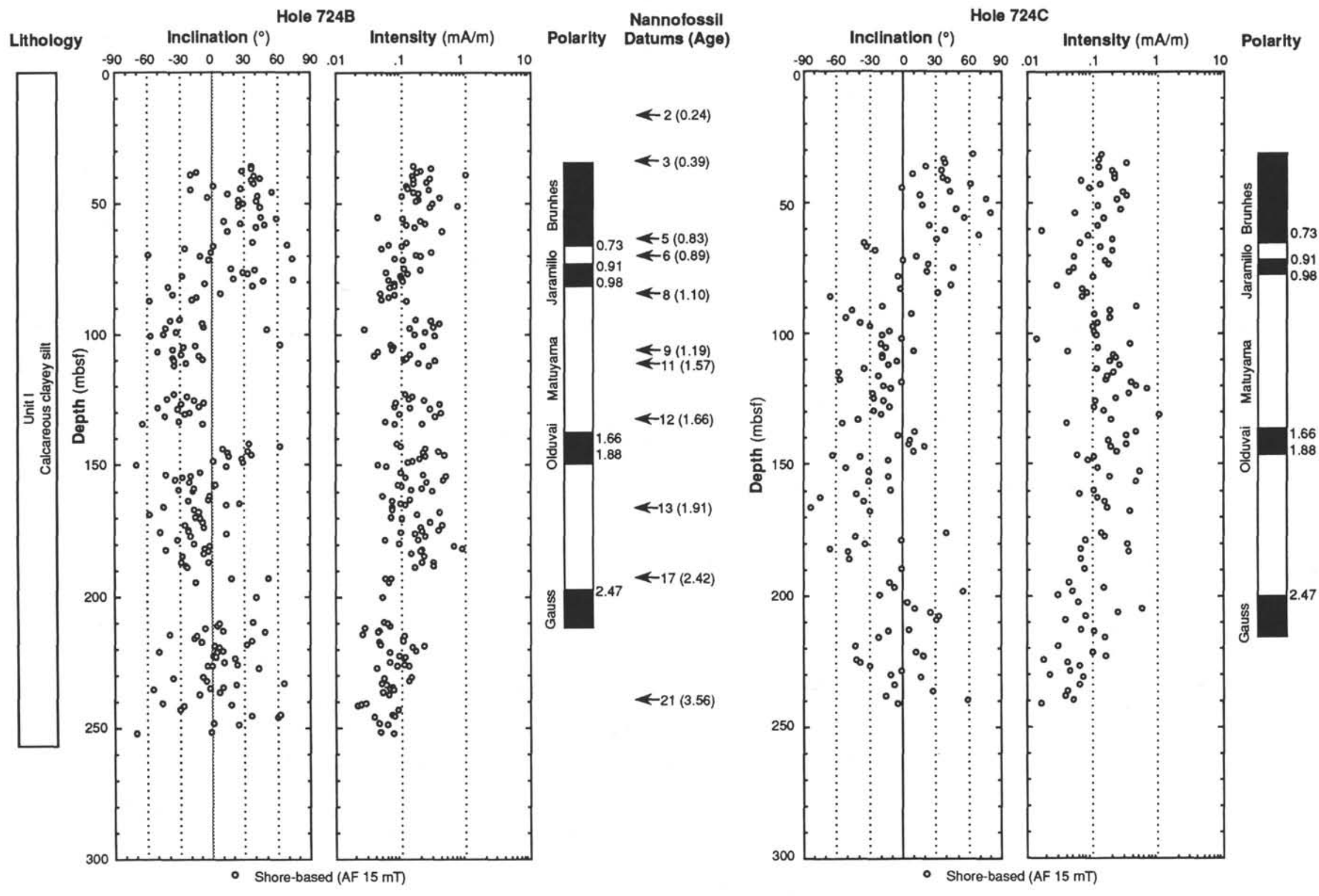

Figure 8. Lithologic units, downhole inclination and intensity plots, polarity assignment, and biostratigraphic datum levels (Spaulding, this volume) for Holes $724 \mathrm{~B}$ and $724 \mathrm{C}$ on the Oman Margin. See Figure 3 for explanation. 
Table 4. Locations of magnetostratigraphic datums in Holes 724B and 724C.

\begin{tabular}{|c|c|c|c|c|c|}
\hline Polarity boundary & $\begin{array}{l}\text { Age } \\
\text { (Ma) }\end{array}$ & Sample & $\begin{array}{l}\text { Depth } \\
\text { (mbsf) }\end{array}$ & Sample & $\begin{array}{l}\text { Depth } \\
\text { (mbsf) }\end{array}$ \\
\hline & & Hole 724B & & Hole $724 \mathrm{C}$ & \\
\hline Brunhe & 0.73 & $8 X-1,105$ & 65.45 & $8 \mathrm{X}-3,115 \mathrm{~cm}$ & 64.35 \\
\hline (C) & & $8 \mathrm{X}$ & 66 & $8 \mathrm{X}$ & 65.09 \\
\hline Top of Ja & 0.91 & $8 \mathrm{X}-5,94 \mathrm{~cm}$ & 71.34 & $9 \mathrm{X}-1,119 \mathrm{~cm}$ & 70.99 \\
\hline (Clr & & $9 \mathrm{x}$ & 74.44 & m & 72.49 \\
\hline Base of Jaramillo & 0.98 & $9 \mathrm{X}-5,114 \mathrm{~cm}$ & 81.14 & $9 X-4,119 \mathrm{~cm}$ & 75.45 \\
\hline (C1r- & & $9 \mathrm{X}-6,4$ & 81.93 & $9 \mathrm{X}-5,119 \mathrm{~cm}$ & 76.99 \\
\hline Top of Olduvai & 1.66 & $15 \mathrm{X}-2,68 \mathrm{~cm}$ & 134.18 & $15 \mathrm{X}-6,100 \mathrm{~cm}$ & 135.90 \\
\hline (C1r/C & & $16 \mathrm{X}-1,19 \mathrm{~cm}$ & 141.89 & $16 \mathrm{X}-1,50 \mathrm{~cm}$ & 137.50 \\
\hline Base of Olduvai & 1.88 & $16 \mathrm{X}-5,116 \mathrm{~cm}$ & 148.86 & $16 \mathrm{X}-6,118 \mathrm{~cm}$ & 145.68 \\
\hline (C2) & & $16 \mathrm{X}-6,50 \mathrm{c}$ & 149.70 & $16 \mathrm{X}-7,38 \mathrm{~cm}$ & 146.38 \\
\hline Matuyama/Gauss & 2.47 & $21 \mathrm{X}-3,123 \mathrm{~cm}$ & 194.23 & $22 \mathrm{X}-4,31 \mathrm{~cm}$ & 199.61 \\
\hline$(\mathrm{C} 2 \mathrm{r}$ & & $22 \mathrm{X}-1,66 \mathrm{~cm}$ & 200.36 & $22 \mathrm{X}-6,28 \mathrm{~cm}$ & 202.58 \\
\hline
\end{tabular}

datums are unclear, the dominant negative inclinations below 100 mbsf suggest a correlation to the Matuyama Chronozone (C1r). The normal inclinations around $105 \mathrm{mbsf}$, confirmed by stepwise AF demagnetization, may represent the Jaramillo (C1r1) Subchronozone. The sample from 126.05 mbsf (Sample 117$725 \mathrm{C}-14 \mathrm{X}-2,45 \mathrm{~cm}$ ) has a highly stable magnetization. This horizon is characterized by positive inclination and relatively high intensity (Fig. 9), and the magnetization is possibly attributable to a secondary overprint.

\section{Site 726}

A single hole was drilled at Site 726 in a water depth of about $330 \mathrm{~m}$, which was the landward end of the depth transect across the Oman continental margin (Fig. 1). The section to the depth of 186.3 mbsf consists of two lithologic units, the Holocene to late Miocene hemipelagic silty clays including sandy lag deposits (Unit I, 0-131.1 mbsf) and the sparsely recovered shallow water limestone of Eocene(?) age (Unit II). Samples for magnetic measurements were obtained from the silty clays of Unit I. Within Unit I, a hiatus between the upper Pliocene and the Pleistocene was identified at about 64 mbsf (between Cores 117-726A-7X and -8X).

More than half the samples were demagnetized in AF's of 5 or $10 \mathrm{mT}$ on board the ship. Inclination plots suggested that the section is normally magnetized down to about 39 mbsf. Between this level and the hiatus at about $64 \mathrm{mbsf}$, the section had mostly negative inclinations, including several normal polarity intervals. The samples above 100 mbsf generally displayed a characteristic magnetization, which was linearly decayed toward the origin by shore-based AF demagnetization over $10 \mathrm{mT}$ (Fig. 10). Most of the samples subjected to thermal demagnetization showed erratic changes in direction after heating to $200^{\circ} \mathrm{C}$, probably due to production of an unstable magnetic phase.

Figure 11 shows the inclination plots obtained after $15 \mathrm{mT}$ AF demagnetization. This result is consistent with the shipboard data. Two nannofossil datums (LAD of Reticulofenestra asanoi $\mathrm{n}$. sp. and FAD of Gephyrocapsa parallela) which predate the Brunhes/Matuyama $(\mathrm{Cl} / \mathrm{C} 1 \mathrm{r})$ boundary (Takayama and Sato, 1987) occur in the lower part of Core 117-726A-4H between 32.98 and 35.30 mbsf (Spaulding, this volume). We, therefore, tentatively assumed the polarity boundary at $39 \mathrm{mbsf}$ as the base of the Jaramillo Subchronozone (C1r-1). Reversed polarity data correlative to the interval between the Jaramillo Subchronozone (C1r-1) and the Brunhes Chronozone (C1) were not detected either in the inclination plot or in the relative declination data for Core $117-726 \mathrm{~A}-4 \mathrm{H}$. This may be due to a relatively low accumulation rate around the Brunhes/Matuyama $(\mathrm{Cl} / \mathrm{C} 1 \mathrm{r})$ boundary. Assignment of the normal polarity interval between 55 and $60 \mathrm{mbsf}$ to the polarity time scale is difficult as the occurrence of nannofossil datums, LAD of Helicosphaera sellii, LAD of Calcidiscus macintyrei, and FAD of Gephyrocapsa caribbeanica (Spaulding, this volume), suggests that this interval is placed between the Cobb Mountain "event" and the Olduvai Subchronozone (C2) (Takayama and Sato, 1987). The section below the hiatus at 64 mbsf is characterized by frequent polarity changes, and probably corresponds to the Gauss $(\mathrm{C} 2 \mathrm{~A})$, Gilbert (C3r), and preceding Chrons in the late Miocene. Correlation of this interval to the polarity time scale is not possible for the lack of continuous core recovery and dense sampling.

\section{Site 727}

Site 727 is located near the center of the upper slope basin to the east of Site 726 , in a water depth about $915 \mathrm{~m}$ corresponding to the middle of the oxygen minimum zone (Fig. 1). The average sedimentation rate is high, about $95 \mathrm{~m} / \mathrm{m}$.y. The late Pliocene to Holocene section, which consists of homogeneous marly nannofossil ooze and calcareous clayey silt, was drilled to a total depth of 182.4 mbsf with almost $100 \%$ recovery.

The NRM of one sample per section from Hole 727A was measured after AF demagnetization at 5 or $10 \mathrm{mT}$ on board the ship. Downhole plots of the magnetic inclinations indicated that the section is divided into at least five polarity zones, and is assigned to the Brunhes (C1) Chronozone to the Olduvai Subchronozone (C2). The rest of samples were subjected to shorebased analysis. Stepwise AF demagnetization was made on most samples around the tentative polarity boundaries. A characteristic magnetization was mostly detected over the coercivity range above $5 \mathrm{mT}$ (Fig. 10), while the NRM intensity was significantly reduced to the order of $0.1 \mathrm{~mA} / \mathrm{m}$.

While the boundaries of the Jaramillo Subchronozone (C1r1) were confirmed or further confined, horizons of the other datum levels were revised (Table 5; Fig. 12). Shore-based measurements revealed that several samples above the tentative position of the Brunhes/Matuyama $(\mathrm{Cl} / \mathrm{Clr})$ boundary ( $~ 82 \mathrm{mbsf}$ in Core 117-727A-9H) had reversed polarity (Fig. 12). As no declination change was observed in Core $117-727 \mathrm{~A}-9 \mathrm{H}$, we placed the boundary between Cores $117-727 \mathrm{~A}-8 \mathrm{H}$ and $-9 \mathrm{H}$, just above the first negative inclination data $(\sim 76 \mathrm{mbsf})$. Magnetic intensities were less than $0.1 \mathrm{~mA} / \mathrm{m}$ below $150 \mathrm{mbsf}$, and reliable results were not observed on board the ship. The exact horizon of the base of the Olduvai Subchronozone (C2) is unclear either in the shore-based results. The mean inclination for the normal polarity intervals is $33^{\circ} \pm 3^{\circ}$, which agree with the inclination of the geocentric axial dipole field $\left(32.7^{\circ}\right)$ at this site $\left(17^{\circ} 46^{\prime} \mathrm{N}\right)$. The mean inclination for the reversed polarity inter- 
Hole 725C

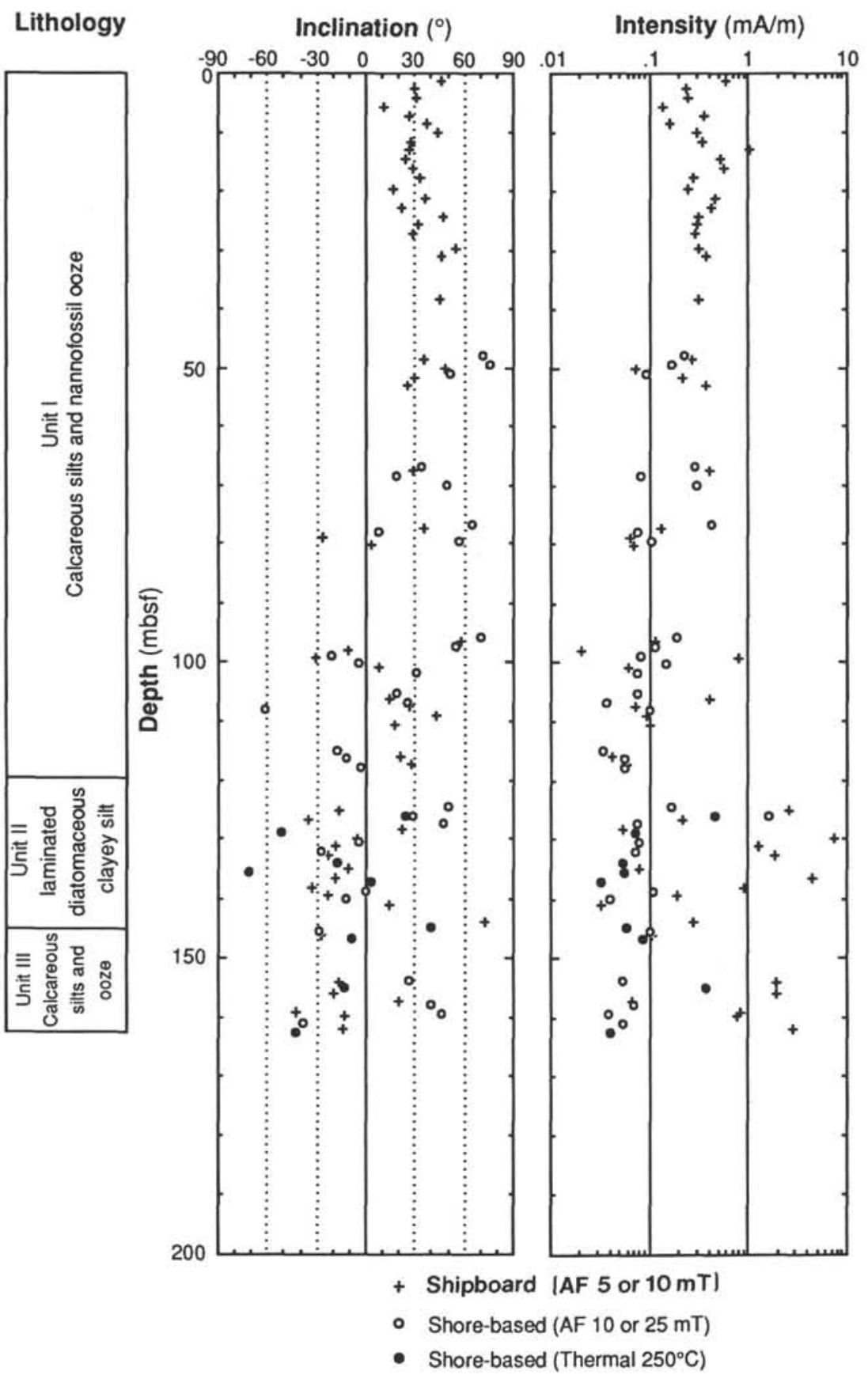

Figure 9. Lithologic units and downhole inclination and intensity plots for Hole $725 \mathrm{C}$ on the Oman Margin.

vals is $22^{\circ} \pm 4^{\circ}$, and shallower than the expected value as at Site 724.

As shown in Figure 12, the assignment to the polarity time scale is concordant with the nannofossil biostratigraphy (Spaulding, this volume). Occurrence of the nannofossil datums in Hole $727 \mathrm{~A}$ is consistent with their ages previously estimated mainly based on the magnetostratigraphy of DSDP Leg 94 sediments from the North Atlantic Ocean (Takayama and Sato, 1987; Clement and Robinson, 1987).
Site 728

Site 728 is located near the center of the seaward slope basin which is deeper and smaller than the upper slope basin drilled at Sites 723 and 727 (Fig. 1). The water depth of Site 728, about $1430 \mathrm{~m}$, corresponds to a deep-water part of a depth transect crossing the oxygen minimum zone. The sedimentary sequence was cored to a total depth of about $350 \mathrm{mbsf}$ in Holes 728A and $728 \mathrm{~B}$ with a recovery rate nearly of $100 \%$. The section essen- 


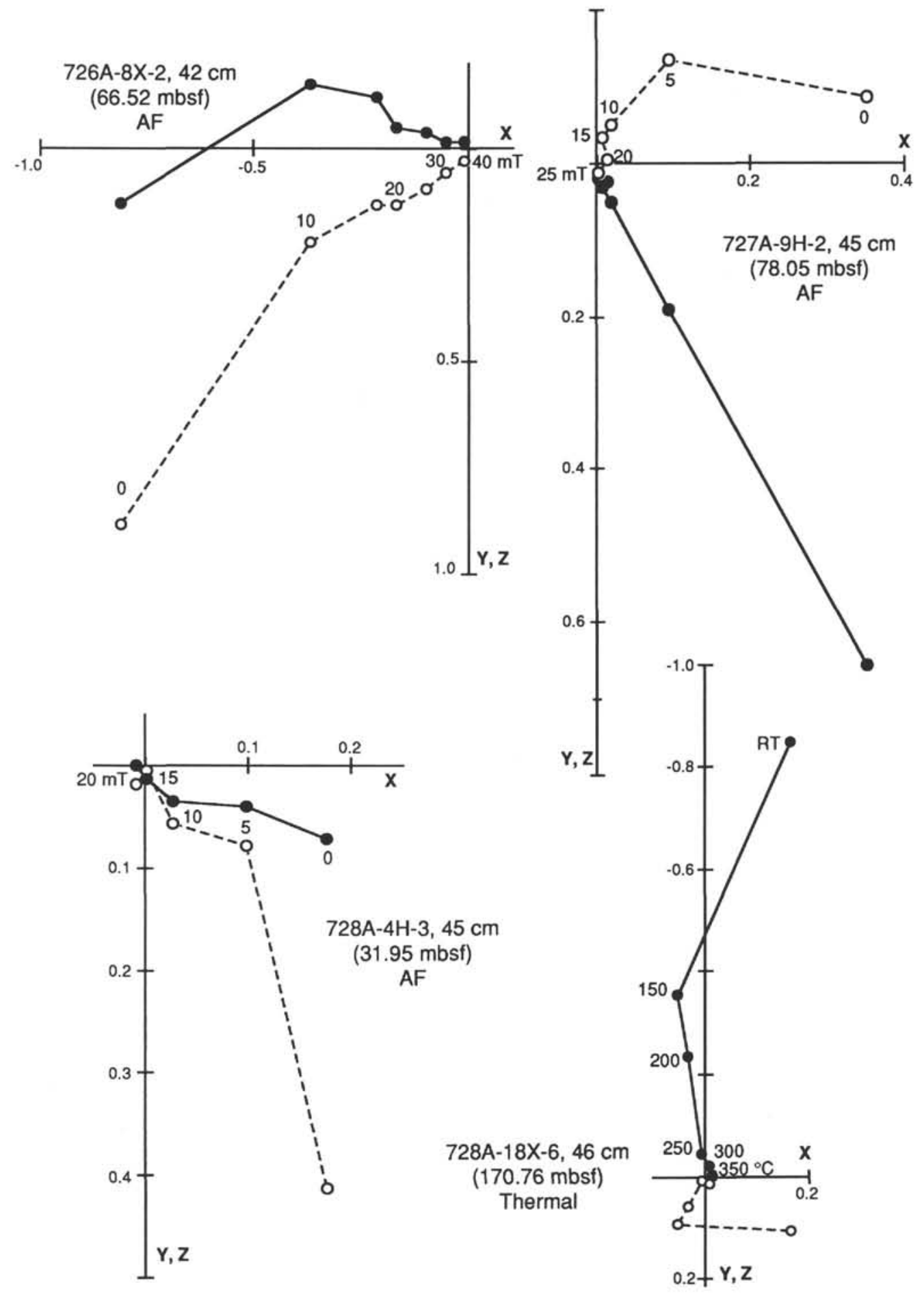

Figure 10. Examples of AF and thermal demagnetization data from the Oman Margin Sites 726, 727, and 728. The demagnetization temperatures are given in degrees celsius for some points. See Figure 2 for explanation.

tially comprises marly nannofossil ooze extending from the Holocene to the late Miocene in age.

Paleomagnetic measurements were made on samples from Hole 728A. One of two samples per section was demagnetized at a blanket AF field of $10 \mathrm{mT}$ on board the ship. Clear records of magnetic polarity changes were obtained for the upper 200 $\mathrm{m}$; the section was divided into at least 13 polarity zones, and most of the magnetostratigraphic datums in the Gauss (C2A) and Gilbert (C2Ar to C3.3) were detected. On shore, the other set of samples were demagnetized also at $10 \mathrm{mT}$, after stepwise $\mathrm{AF}$ and thermal demagnetization of the samples around the polarity boundaries (Fig. 10). The NRM intensities of samples above $50 \mathrm{mbsf}$ were reduced to the noise level of the cryogenic magnetometer (around $0.01 \mathrm{~mA} / \mathrm{m}$ ) after the demagnetization at $15 \mathrm{mT}$. The samples between 50 and $200 \mathrm{mbsf}$ had relatively stable magnetization with higher coercivity and intensity. The 


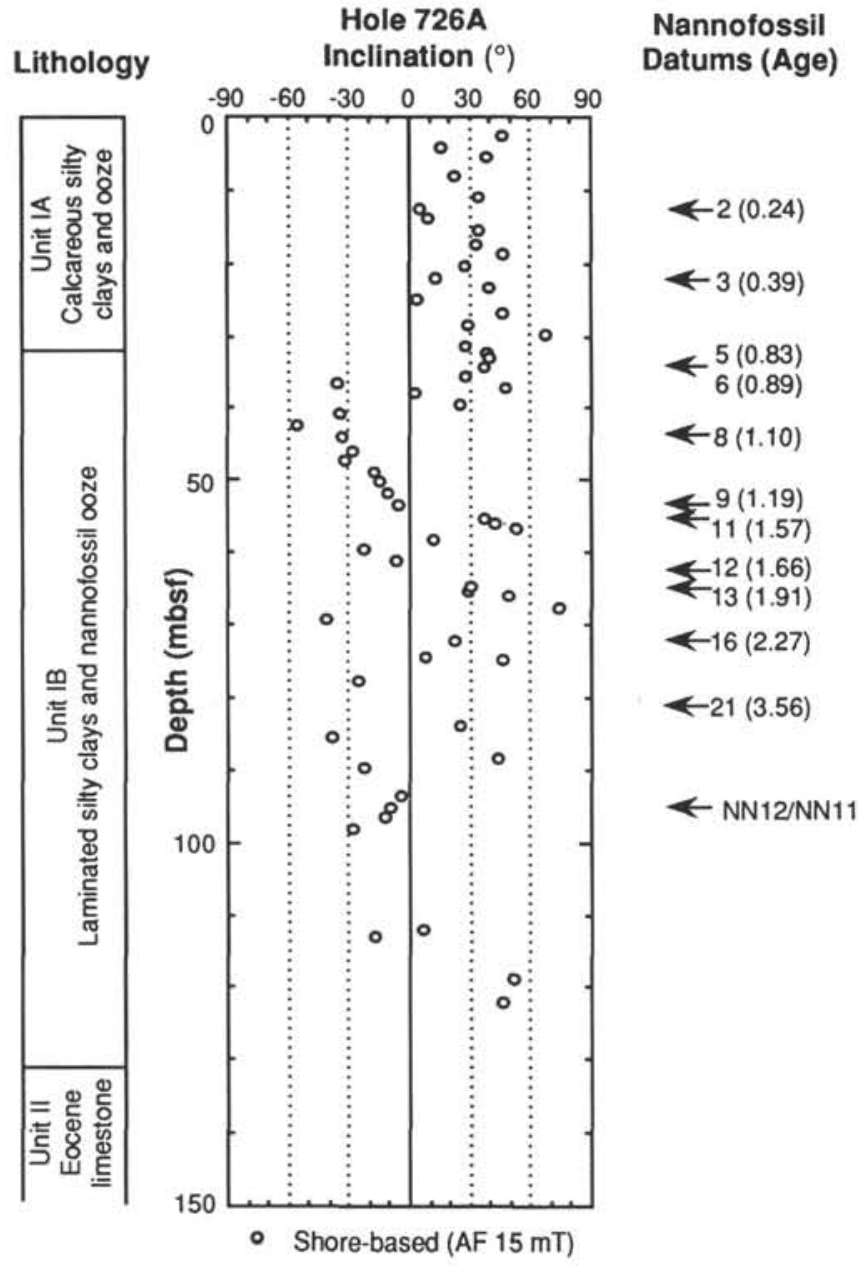

Figure 11. Lithologic units, downhole inclination plots, and biostratigraphic datum levels (Spaulding, this volume) for Hole $726 \mathrm{~A}$ on the Oman Margin. See Figure 3 for explanation.

Table 5. Locations of magnetostratigraphic datums in Holes 727A.

\begin{tabular}{|c|c|c|c|}
\hline Polarity bo & $\begin{array}{l}\text { Age } \\
\text { (Ma) }\end{array}$ & Sample & $\begin{array}{l}\text { Depth } \\
\text { (mbsf) }\end{array}$ \\
\hline $\begin{array}{l}\text { Brunhes/ } \\
\text { (C1/C }\end{array}$ & 0.73 & & $\begin{array}{l}5.80 \\
6.50\end{array}$ \\
\hline $\begin{array}{l}\text { Top of Jaramillo } \\
\text { (C1r/C1r-1) }\end{array}$ & 0.91 & $\begin{array}{l}10 \mathrm{H}-8,85 \mathrm{~cm} \\
11 \mathrm{X}-1,43 \mathrm{~cm}\end{array}$ & $\begin{array}{r}\text { a } 95.87 \\
95.83\end{array}$ \\
\hline $\begin{array}{c}\text { Base of Jaramillo } \\
\text { (C1r-1/C1r) }\end{array}$ & 0.98 & $\begin{array}{l}11 X-6,124 \mathrm{~cm} \\
11 X-7,29 \mathrm{~cm}\end{array}$ & $\begin{array}{l}104.14 \\
104.69\end{array}$ \\
\hline $\begin{array}{l}\text { Top of Olduvai } \\
\text { (C1r/C2) }\end{array}$ & 1.66 & $\begin{array}{l}16 \mathrm{X}-7,12 \mathrm{~cm} \\
17 \mathrm{X}-1,25 \mathrm{~cm}\end{array}$ & $\begin{array}{l}152.72 \\
153.55\end{array}$ \\
\hline
\end{tabular}

a The ODP depth calculated for extra Section 8 of $91 \mathrm{~cm}$ long. The true depth should be less than $95.40 \mathrm{mbsf}$, the bottom of Core 117-731A-10H and the top of Core 117-731A-11X.

characteristic magnetization of this interval was also detected in thermal demagnetization in the temperature range from $150^{\circ}$ to $300^{\circ} \mathrm{C}$ (Fig. 10). Below $210 \mathrm{mbsf}$, magnetic components were rarely characterized in both $\mathrm{AF}$ and thermal demagnetizations.

Figure 13 shows plots of magnetic inclinations and intensities after $10 \mathrm{mT}$ AF demagnetization measured on board the ship and on shore. Polarity changes above $200 \mathrm{mbsf}$ are generally consistent between the two data sets, so that the horizons of most magnetostratigraphic datums were confined to intervals of about $1 \mathrm{~m}$ (Table 6). Above the possible horizon of the base of the Jaramillo Subchronozone $(\mathrm{C} 1 \mathrm{r}-1 / \mathrm{C} 1 \mathrm{r})$, a reversed polarity interval was found from about 36 to 38 mbsf, represented by two negative inclination data and an additional result of thermal demagnetization. These data may define the Brunhes/Matuyama boundary $(\mathrm{Cl} / \mathrm{Cl} \mathrm{r})$ and the top of the Jaramillo $(\mathrm{C} 1 \mathrm{r}$ / $\mathrm{C} 1 \mathrm{r}-1)$. In the nannofossil biostratigraphy (Spaulding, this volume), the FAD of Gephyrocapsa caribbeanica and the LAD of Discoaster brouweri occur between 61.25 and 64.25 mbsf within Core 117-728A-7H. While at Site 724 and 727 the Olduvai Subchronozone $(\mathrm{C} 2)$ was observed between these datum levels, neither positive inclinations nor significant declination swings were detected in this core of Hole 728A. The absence of the Olduvai (C2) is probably attributable to a relatively low accumulation rate around this horizon (about $10 \mathrm{~m} / \mathrm{m} . \mathrm{y}$; Prell, Niitsuma, et al., 1989).

In the interval between 70 and $210 \mathrm{mbsf}$, an extended magnetostratigraphic record in the Pliocene was obtained (Fig. 13, Table 6). This interval was correlated to the Gauss (C2A) and Gilbert (C2Ar to C3.3) Chronozones, including the Cochiti, Nunivak, Sidufjall, and Thvera Subchronozones (C3.1 through C3.3). These assignments were checked using the nannofossil datums, the LAD of Reticulofenestra pseudoumbilica (NN16/ NN15) and the LAD of Phormostichoartus doliolum, (NN12/ NN11) (Spaulding, this volume). They are also concordant with the published ages of the radiolarian events, the LAD of Phormostichoartus doliolum, FAD of Amphirhopalum ypsilon, FAD of Spongaster tetras, and LAD of Solenosphaera omnitubus (Nigrini, this volume; Johnson and Nigrini, 1985; Johnson et al., 1989). The magnetostratigraphic results suggest that the sedimentation rate was higher in the Pliocene, especially during the late and middle Gilbert Chron (C2Ar and C3). Correlation of the polarity zones between 100 and 200 mbsf to the normal subchronozones $(\mathrm{C} 3)$ in the Gilbert gives sedimentation rate of about $90 \mathrm{~m} / \mathrm{m}$.y.

The mean inclination for the normal polarity intervals above $210 \mathrm{mbsf}$ is $31^{\circ} \pm 4^{\circ}$, which is consistent with the expected value $\left(32.5^{\circ}\right.$ at $\left.17^{\circ} 41^{\prime} \mathrm{N}\right)$. The inclinations of the reversed polarity parts give the shallower mean inclination $\left(25^{\circ} \pm 3^{\circ}\right)$ as Sites 724 and 728 .

\section{Site 730}

Site 730 is located in a water depth of $1065.8 \mathrm{~m}$ to the east of a ridge separating the upper and lower slope basins on the Oman continental margin (Fig. 1). Three lithologic units were recognized in Hole $730 \mathrm{~A}$ drilled to a total depth of $403.9 \mathrm{mbsf}$. Unit I consists of the Pleistocene marly calcareous ooze extending to the depth of $15.2 \mathrm{mbsf}$ in Core $117-730 \mathrm{~A}-2 \mathrm{H}$, where a major hiatus was encountered. Below the hiatus, the middle to upper Miocene diatomaceous marly nannofossil ooze/silty clays (Unit II) were cored down to about $200 \mathrm{mbsf}$, and then the lower to middle Miocene marly chalks (Unit III) were obtained with a decreased recovery rate.

The NRM of the samples above 150 mbsf was measured after AF demagnetization at 5 or $10 \mathrm{mT}$ on board the ship. The most prominent feature of the paleomagnetic record of Site 730 is the normal polarity interval between 50 and 110 mbsf (Fig. 14). Because this interval was correlated to nannofossil zones NN9 to NN7 (Spaulding, this volume), a part of this normal polarity zone is possibly correlative with Chronozone 11 (C5) dated from 10.42 to $8.92 \mathrm{Ma}$. However, stepwise AF and thermal demagnetization on shore showed that some of the samples from this interval had a magnetic component of normal polarity, which was largely removed in an AF of $20 \mathrm{mT}$, or by heating to $250^{\circ} \mathrm{C}$. Magnetic intensities of most samples decreased to around $0.01 \mathrm{~mA} / \mathrm{m}$ after 10 or $15 \mathrm{mT} \mathrm{AF} \mathrm{demagnetization,} \mathrm{at} \mathrm{which}$ 
Hole 727 A

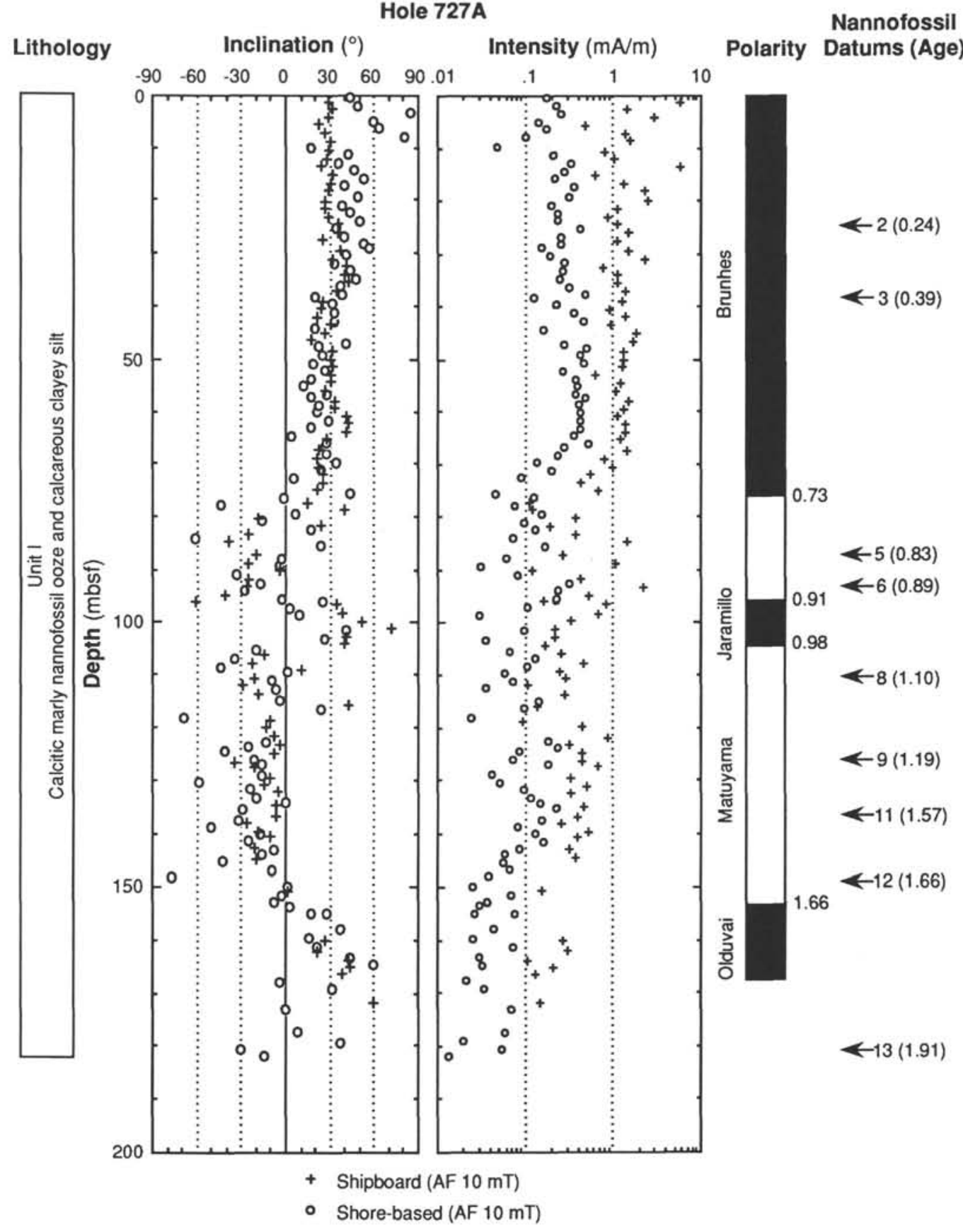

Figure 12. Lithologic units, downhole inclination and intensity plots, polarity assignment, and biostratigraphic datum levels (Spaulding, this volume) for Hole 727A on the Oman Margin. See Figure 3 for explanation.

point a characteristic component could not be detected. In the results of blanket $\mathrm{AF}$ demagnetization at $10 \mathrm{mT}$ on shore, positive inclinations were dominant above 75 mbsf. Below this level, the NRM's showed a biased distribution in the horizontal direction, possibly reflecting VRM acquired after sampling. NRM's of the samples below $150 \mathrm{mbsf}$ had weak intensities and rather scattered directions, and provide no clear polarity information.

\section{SUMMARY}

The magnetic measurements of discrete samples defined horizons of some polarity boundaries for the Neogene sediments on the Owen Ridge and the Oman margin. The magnetostratigraphy was resolved only for the uppermost interval above 200 mbsf in most of the holes, and not recognized at all for some sites (e.g., Site 723). At the Owen Ridge sites, polarity intervals of about or less than $10^{5}$ years, such as the Olduvai (C2), Kaena (C2A-1), and Mammoth (C2A-2) subchronozones, were not clearly detected, while the major chronozones were identified. The Olduvai (C2) Subchronozone was not detected either at Site 728 on the Oman Margin, where the polarity changes within the Gauss (C2A) and Gilbert ( $\mathrm{C} 2 \mathrm{Ar}$ to $\mathrm{C} 3 \mathrm{r}$ ) chronozones were clearly recorded.

The ambiguity in the magnetostratigraphic interpretation was primarily caused by the low magnetic intensities, encountered in most sections except the turbidite sequence of the Owen Ridge sites (Unit IV). The NRM intensities of the pelagic or hemipe- 
Hole 728A

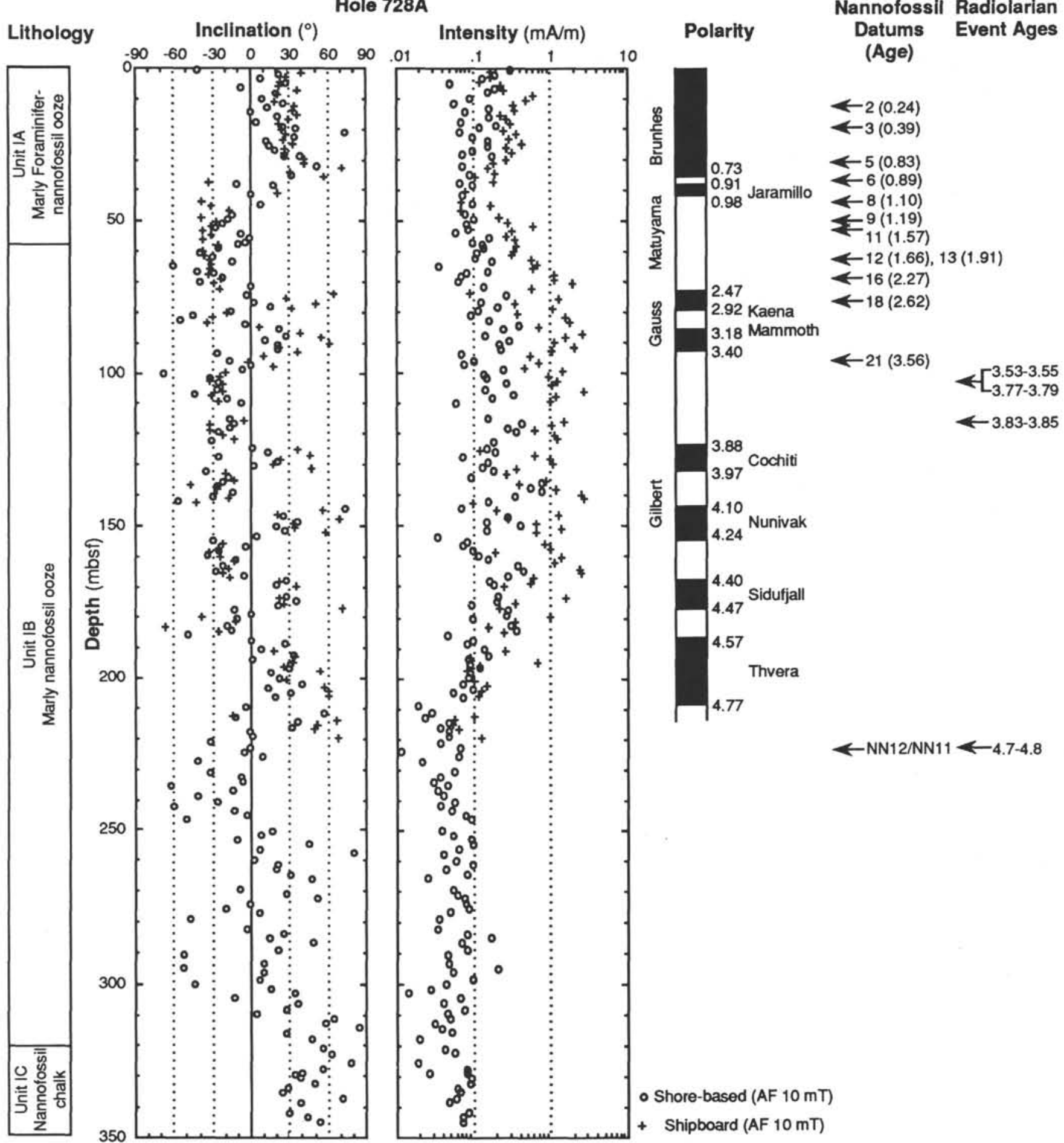

Figure 13. Lithologic units, downhole inclination and intensity plots, polarity assignment, and biostratigraphic datum levels (Spaulding, this volume; Nigrini, this volume) for Holes $728 \mathrm{~A}$ on the Oman Margin. See Figure 3 for explanation.

lagic sediments were significantly reduced by AF demagnetization up to $20 \mathrm{mT}$ or thermal treatment at around $200^{\circ} \mathrm{C}$, generally to the order of $0.1 \mathrm{~mA} / \mathrm{m}$. The low NRM intensity is presumably attributed to reduction diagenesis of titanomagnetite to iron sulfide. Progress of sulfate reduction was observed both at the Owen Ridge sites and the Oman Margin sites.
Polarity reversals in the Pleistocene were clearly observed at Sites 724 and 727 on the Oman Margin. The sedimentation rate at these sites were typically $80-100 \mathrm{~m} / \mathrm{m}$.y., about three times as high as the equivalent sequences on the Owen Ridge (about 30 $\mathrm{m} / \mathrm{m}$.y.). The higher sedimentation rates are possibly advantageous to the fidelity of paleomagnetic records. Although Site 
Table 6. Locations of magnetostratigraphic datums in Holes 728A.

\begin{tabular}{|c|c|c|c|}
\hline Polarity boundary & $\begin{array}{l}\text { Age } \\
(\mathrm{Ma})\end{array}$ & Sample & $\begin{array}{l}\text { Depth } \\
\text { (mbsf) }\end{array}$ \\
\hline $\begin{array}{l}\text { Brunhes/Matuyama } \\
\text { (C1/C1r) }\end{array}$ & 0.73 & $\begin{array}{l}4 \mathrm{H}-5,120 \mathrm{~cm} \\
4 \mathrm{H}-6,45 \mathrm{~cm}\end{array}$ & $\begin{array}{l}35.70 \\
36.45\end{array}$ \\
\hline $\begin{array}{l}\text { Top of Jaramillo } \\
(\mathrm{C} 1 \mathrm{r} / \mathrm{C} 1 \mathrm{r}-1)\end{array}$ & 0.91 & $\begin{array}{l}4 \mathrm{H}-7,45 \mathrm{~cm} \\
5 \mathrm{H}-1,45 \mathrm{~cm}\end{array}$ & $\begin{array}{l}37.95 \\
38.45\end{array}$ \\
\hline $\begin{array}{c}\text { Base of Jaramillo } \\
\text { (C1r-1/C1r) }\end{array}$ & 0.96 & $\begin{array}{l}5 \mathrm{H}-2,120 \mathrm{~cm} \\
5 \mathrm{H}-3,120 \mathrm{~cm}\end{array}$ & $\begin{array}{l}40.72 \\
42.20\end{array}$ \\
\hline $\begin{array}{c}\text { Matuyama/Gauss } \\
(\mathrm{C} 2 \mathrm{r} / \mathrm{C} 2 \mathrm{~A})\end{array}$ & 2.47 & $\begin{array}{l}5 \mathrm{H}-4,120 \mathrm{~cm} \\
5 \mathrm{H}-5,120 \mathrm{~cm}\end{array}$ & $\begin{array}{l}72.20 \\
73.70\end{array}$ \\
\hline $\begin{array}{l}\text { Top of Kaena } \\
\qquad(C 2 A / C 2 A-1)\end{array}$ & 2.92 & $\begin{array}{l}9 \mathrm{H}-2,120 \mathrm{~cm} \\
9 \mathrm{H}-3,45 \mathrm{~cm}\end{array}$ & $\begin{array}{l}78.80 \\
79.55\end{array}$ \\
\hline $\begin{array}{l}\text { Base of Mammoth } \\
\text { (C2A-2/C2A) }\end{array}$ & 3.18 & $\begin{array}{l}9 \mathrm{H}-6,120 \mathrm{~cm} \\
10 \mathrm{X}-1,45 \mathrm{~cm}\end{array}$ & $\begin{array}{l}84.60 \\
66.15\end{array}$ \\
\hline $\begin{array}{l}\text { Gauss/Gilbert } \\
\text { (C2A/C2Ar) }\end{array}$ & 3.40 & $\begin{array}{l}10 X-5,120 \mathrm{~cm} \\
10 X-6,45 \mathrm{~cm}\end{array}$ & $\begin{array}{l}92.90 \\
93.65\end{array}$ \\
\hline $\begin{array}{l}\text { Top of Cochiti } \\
\text { (C2Ar/C3.1) }\end{array}$ & 3.88 & $\begin{array}{l}13 X-6,45 \mathrm{~cm} \\
14 X-1,115 \mathrm{~cm}\end{array}$ & $\begin{array}{l}122.45 \\
125.35\end{array}$ \\
\hline $\begin{array}{l}\text { Base of Cochiti } \\
(\mathrm{C} 2 \mathrm{Ar} / \mathrm{C} 3.1)\end{array}$ & 3.97 & $\begin{array}{l}14 X-5,120 \mathrm{~cm} \\
14 X-6,45 \mathrm{~cm}\end{array}$ & $\begin{array}{l}131.40 \\
132.15\end{array}$ \\
\hline $\begin{array}{l}\text { Top of Nunivak } \\
\text { (C3.1r/C3.2) }\end{array}$ & 4.10 & $\begin{array}{l}15 X-6,120 \mathrm{~cm} \\
16 X-1,45 \mathrm{~cm}\end{array}$ & $\begin{array}{l}142.60 \\
144.10\end{array}$ \\
\hline $\begin{array}{r}\text { Base of Nunivak } \\
\text { (C3.2/C3.2r) }\end{array}$ & 4.24 & $\begin{array}{l}17 X-1,53 \mathrm{~cm} \\
17 X-2,120 \mathrm{~cm}\end{array}$ & $\begin{array}{l}153.63 \\
155.60\end{array}$ \\
\hline $\begin{array}{l}\text { Top of Sidufjall } \\
\text { (C3.2r/C3.2r-1) }\end{array}$ & 4.40 & $\begin{array}{l}18 X-3,128 \mathrm{~cm} \\
16 X-4,49 \mathrm{~cm}\end{array}$ & $\begin{array}{l}167.08 \\
167.79\end{array}$ \\
\hline $\begin{array}{l}\text { Base of Sidufjall } \\
\text { (C3.2r-1/C3.2r) }\end{array}$ & 4.47 & $\begin{array}{l}19 \mathrm{X}-3,125 \mathrm{~cm} \\
19 \mathrm{X}-4,49 \mathrm{~cm}\end{array}$ & $\begin{array}{l}176.75 \\
177.49\end{array}$ \\
\hline $\begin{array}{l}\text { Top of Thvera } \\
\text { (C3.2r/C3.3) }\end{array}$ & 4.57 & $\begin{array}{l}20 \mathrm{X}-3,58 \mathrm{~cm} \\
20 \mathrm{X}-3,112 \mathrm{~cm}\end{array}$ & $\begin{array}{l}185.78 \\
186.32\end{array}$ \\
\hline $\begin{array}{l}\text { Base of Thvera } \\
\text { (C3.3/C } 3.3 \mathrm{r} \text { ) }\end{array}$ & 4.77 & $\begin{array}{l}22 X-5,34 \mathrm{~cm} \\
22 X-5,120 \mathrm{~cm}\end{array}$ & $\begin{array}{l}207.84 \\
208.70\end{array}$ \\
\hline
\end{tabular}

723 had the highest accumulation rate about $175 \mathrm{~m} / \mathrm{m}$.y., quality of the paleomagnetic record was significantly affected by core disturbance by gas expansion, as discussed before.

Extended reversal records of the Pliocene were found at Site 722 on the Owen Ridge and Site 728 on the Oman Margin, and correlated to the Gauss (C2A) and Gilbert (C2Ar to C3r) Chronozones. The interval from 50 to 200 mbsf at Site 728 provided the best reversal stratigraphy including the Cochiti, Nunivak, Sidufjall, and Thvera subchronozones (C3) in the Gilbert Chronozone. The NRM intensities of this interval were generally between 0.1 and $1.0 \mathrm{~mA} / \mathrm{m}$, higher than the other horizons (Fig. 13). A similar interval of higher NRM intensity was found from 80 to 190 mbsf at Site 724 , which corresponds to the Matuyama Chronozone including the Olduvai Subchronozone (C2). These two intervals coincide with the zone of high organic carbon content and abundant terrigenous input mainly in upper Pliocene.

\section{ACKNOWLEDGMENTS}

We sincerely thank Warren Prell, Nobuaki Niitsuma, Kay Emeis, and the shipboard party of Leg 117. John Tauxe and
Bob Wilcox provided invaluable assistance in sampling and measurements on board. We also thank two anonymous reviewers for their constructive comments, and Masayuki Torii for his help and discussions during the shore-based research.

\section{REFERENCES}

Berggren, W. A., Kent, D. V., and Van Couvering, J. A., 1985. The Neogene: Part 2. Neogene geochronology and chronostratigraphy. In Snelling, N. J. (Ed.), The Chronology of the Geological Record. Geol. Soc. London Mem., 10:211-260.

Canfield, D. E., and Berner, R. A., 1987. Dissolution and pyritization of magnetite in anoxic marine sediments. Geochim. Cosmochim. Acta, 51:645-659.

Channell, J.E.T., Hawthorne, T., and Torii, M., 1990. Contrasting magnetic properties in Leg 107 sediments: preservation and alteration of titanomagnetite at adjacent sites. In Kastens, K. A., Mascle, J., et al., Proc. ODP, Sci. Results, 107: College Station, TX (Ocean Drilling Program), 113-128.

Clement, B. M., and Robinson, F., 1987. The magnetostratigraphy of Leg 94 sediments. In Ruddiman, W. F., Kidd, R. B., Thomas, E., et al., Init Repts. DSDP, 94 (Pt. 2): Washington (U. S. Govt. Printing Office), 635-650.

Collinson, D. W., 1983. Methods in Rock Magnetism and Paleomagnetism: London (Chapman and Hall).

Harland, W. B., Cox, A. V., Llewellyn, P. G., Pickton, C.A.G., Smith, D. G., and Walters, R., 1982. A Geologic Time Scale: Cambridge (Cambridge Univ. Press).

Johnson, D. A., and Nigrini, C. A., 1985. Synchronous and time-transgressive Neogene radiolarian datum levels in the equatorial Indian and Pacific Oceans. Mar. Micropaleontol., 9:489-523.

Johnson, D. A., Schneider, D. A., Nigrini, C. A., Caulet, J. P., and Kent, D. V., 1989. Pliocene-Pleistocene radiolarian events and magnetostratigraphic calibrations for the tropical Indian Ocean. Mar. Micropaleontol., 14:33-66.

Karlin, R., and Levi, S., 1983. Diagenesis of magnetic minerals in Recent haemipelagic sediments. Nature, 303:327-330. 1985. Geochemical and sedimentological control of the magnetic properties of hemipelagic sediments. J. Geophys. Res., 90: 10373-10392.

Kobayashi, K., and Nomura, M., 1972. Iron sulfides in the sediment cores from the Sea of Japan and their geophysical implications. Earth Planet. Sci. Lett., 16:200-208.

Kono, M., 1980. Statistics of paleomagnetic inclination data. J. Geophys Res., 85:3878-3882.

Mankinen, E. A., Donnelly, J. M., and Grommé, C. S., 1978. Geomagnetic polarity event recorded at 1.1 m.y. B.P. on Cobb Mountain, Clear Lake volcanic field, California. Geology, 6:653-656.

Prell, W., Niitsuma, N., et al., 1989. Proc. ODP, Init. Repts, 117: College Station, TX (Ocean Drilling Program).

Takayama, T., and Sato, T., 1987. Coccolith biostratigraphy of the North Atlantic Ocean, Deep Sea Drilling Project Leg 94. In Ruddiman, W. F., Kidd, R. B., Thomas, E., et al., Init. Repts. DSDP, 94 (Pt. 2): Washington (U.S. Govt. Printing Office), 651-702.

Date of initial receipt: 5 July 1989

Date of acceptance: 20 February 1990

Ms 117B-180 


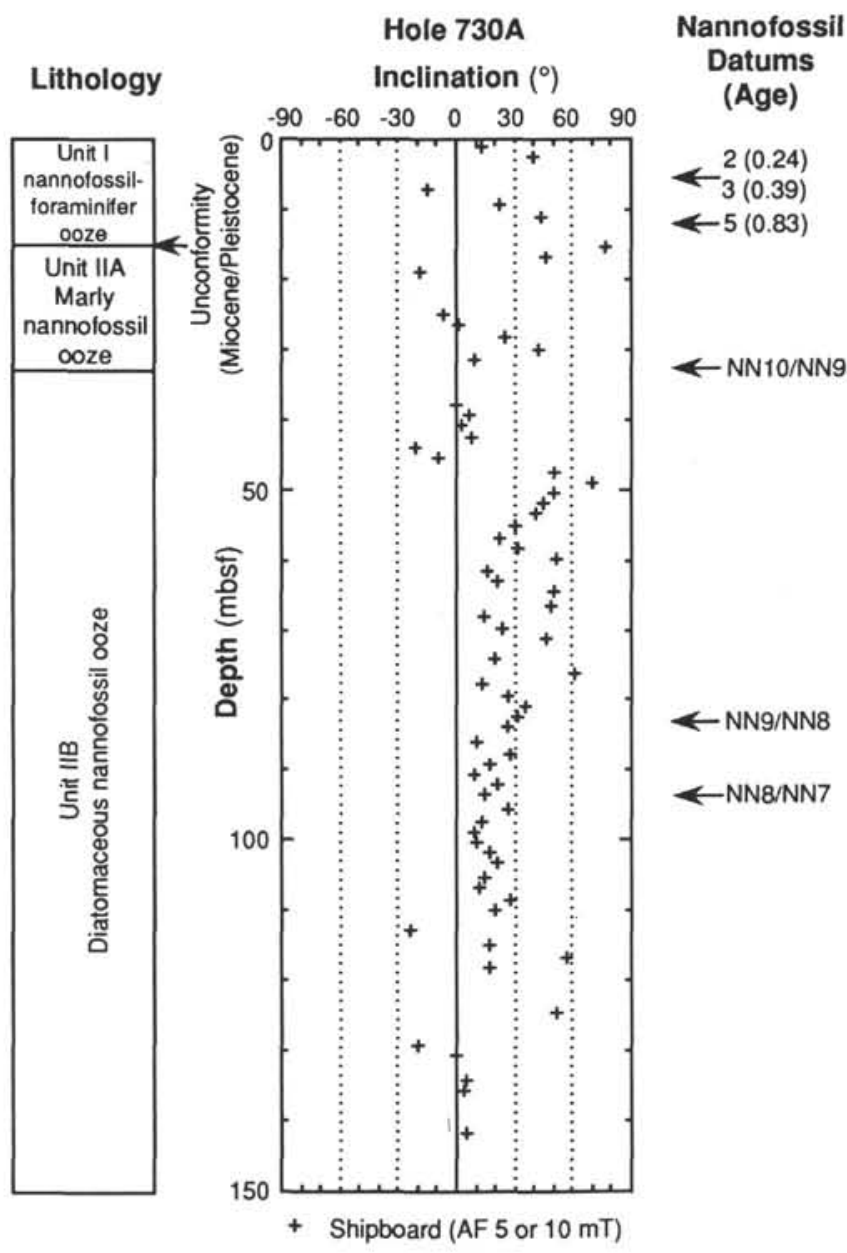

Figure 14. Lithologic units, downhole inclination plots, and biostratigraphic datum levels (Spaulding, this volume) for Hole 730A on the Oman Margin. See Figure 3 for explanation. 